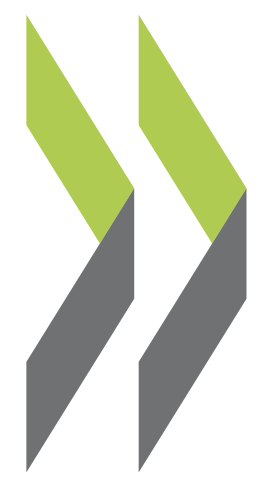

OECD Economics Department Working Papers No. 1152

Fostering a Creative Economy to Drive Korean

Growth
Randall S. Jones, Myungkyoo Kim 
Organisation de Coopération et de Développement Économiques

Organisation for Economic Co-operation and Development

26-Aug-2014

ECONOMICS DEPARTMENT

English - Or. English

Cancels \& replaces the same document of 24 July 2014

\section{FOSTERING A CREATIVE ECONOMY TO DRIVE KOREAN GROWTH}

ECONOMICS DEPARTMENT WORKING PAPER No. 1152

By Randall S. Jones and Myungkyoo Kim

OECD Working Papers should not be reported as representing the official views of the OECD or of its member countries. The opinions expressed and arguments employed are those of the author(s).

Authorised for publication by Robert Ford, Deputy Director, Country Studies Branch, Economics Department.

All OECD Economics Department Working Papers are available through OECD's Internet website at www.oecd.org/eco/workingpapers

JT03361324

Complete document available on OLIS in its original format

This document and any map included herein are without prejudice to the status of or sovereignty over any territory, to the delimitation of international frontiers and boundaries and to the name of any territory, city or area. 
OECD Working Papers should not be reported as representing the official views of the OECD or of its member countries. The opinions expressed and arguments employed are those of the author(s).

Working Papers describe preliminary results or research in progress by the author(s) and are published to stimulate discussion on a broad range of issues on which the OECD works.

Comments on Working Papers are welcomed, and may be sent to the Economics Department, OECD, 2 rue André-Pascal, 75775 Paris Cedex 16, France, or by e-mail to econ.contact@oecd.org.

This document and any map included herein are without prejudice to the status of or sovereignty over any territory, to the delimitation of international frontiers and boundaries and to the name of any territory, city or area.

The statistical data for Israel are supplied by and under the responsibility of the relevant Israeli authorities. The use of such data by the OECD is without prejudice to the status of the Golan Heights, East Jerusalem and Israeli settlements in the West Bank under the terms of international law.

\section{(C) OECD (2014)}

You can copy, download or print OECD content for your own use, and you can include excerpts from OECD publications, databases and multimedia products in your own documents, presentations, blogs, websites and teaching materials, provided that suitable acknowledgment of OECD as source and copyright owner is given. All requests for commercial use and translation rights should be submitted to rights@oecd.org 


\section{ABSTRACT/RÉSUMÉ \\ Fostering a creative economy to drive Korean growth}

A creative economy requires innovation-friendly conditions. Korea's innovation system should be improved by upgrading universities and expanding their role in business $\mathrm{R} \& \mathrm{D}$, while increasing international collaboration in R\&D from its current low level. The returns from Korea's large investment in innovation should be enhanced by improving framework conditions - easing product market regulations, promoting international competition and enhancing labour market flexibility - to encourage the adoption of new technology. Venture businesses and start-ups should play a key role in commercialising innovation. To make venture investment a growth driver, it is important to expand the role of business angels, activate the mergerand-acquisition market and foster entrepreneurship. A creative economy also depends on making SMEs, which account for $87 \%$ of employment, more dynamic. SME policies should be streamlined and improved to promote market-based financing and reduce the negative effects of government funding programmes, which discourage the expansion of SMEs. The growth of small firms also depends on resolving labour market mismatches and taking full advantage of the opportunities afforded by the Internet.

This Working Paper relates to the 2014 OECD Economic Survey of Korea (www.oecd.org/eco/economic-surveykorea.htm).

JEL Classification: L25, L26, M13, O31

Keywords: Creative economy, venture capital investment, innovation system, business angels, start-ups, SMEs, credit guarantees, R\&D, product market regulation, crowd-funding, mergers and acquisitions, knowledge-based capital, entrepreneurship, chaebols

\section{Promouvoir une économie créatrice comme moteur de la croissance coréenne}

Une économie créatrice nécessite des conditions propices à l'innovation. Il conviendrait d'améliorer le système d'innovation en modernisant les universités et en renforçant leur rôle dans la R-D des entreprises, tout en multipliant les collaborations internationales, actuellement peu développées, dans ce domaine. Il conviendrait aussi d'améliorer le rendement des investissements massifs de la Corée dans l'innovation en instaurant un environnement plus favorable - en assouplissant la réglementation des marchés de produits, en favorisant la concurrence internationale et en conférant plus de flexibilité au marché du travail - afin d'encourager l'adoption de technologies nouvelles. Les entreprises à risque et les jeunes entreprises devraient jouer un rôle de premier plan dans la mise sur le marché des innovations. Pour que l'investissement en capital-risque soit vecteur de croissance, il est primordial de renforcer le rôle des investisseurs providentiels, de développer le marché des fusions-acquisitions et de favoriser l'entrepreneuriat. Une économie créatrice est aussi une économie qui dynamise le secteur des PME, lequel représente $87 \%$ de l'emploi. Les politiques en faveur des PME doivent être rationnalisées et optimisées pour promouvoir les financements de marché et atténuer l'impact négatif des aides publiques, qui n'incitent pas les PME à se développer. Enfin, le développement des petites entreprises dépend aussi de la capacité à résoudre l'inadéquation entre offre et demande sur le marché du travail et à tirer pleinement profit des opportunités offertes par Internet.

Ce Document de travail se rapporte à l'Étude économique de l'OCDE de la Corée, 2014 (www.oecd.org/fr/eco/etudes/coree.htm).

Classification JEL : L25, L26, M13, O31

Mots clés : Corée, économie créative, investissements en capital-risque, système d'innovation, investisseurs providentiels, jeunes entreprises, PME, garanties de crédit, R-D, réglementation des marchés de produits, financement participatif, fusions et acquisitions, capital connaissance, entrepreneuriat, chaebols 


\section{TABLE OF CONTENTS}

FOSTERING A CREATIVE ECONOMY TO DRIVE KOREAN GROWTH ........................................... 5

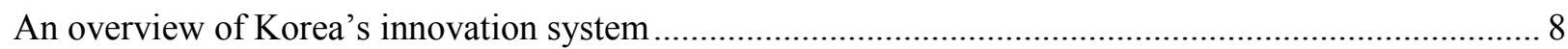

The return on investment in innovation could be increased by improving the innovation system.......... 8

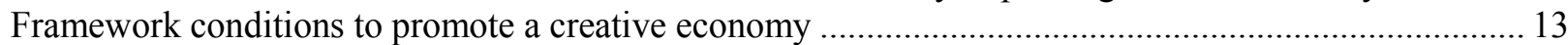

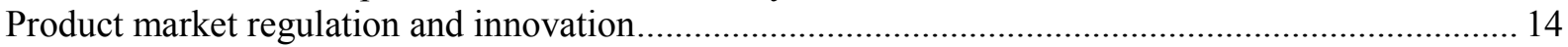

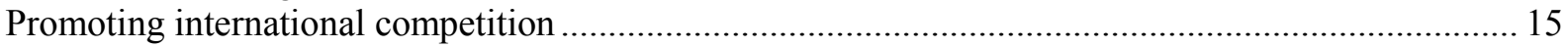

Labour market flexibility: relaxing employment protection.......................................................... 16

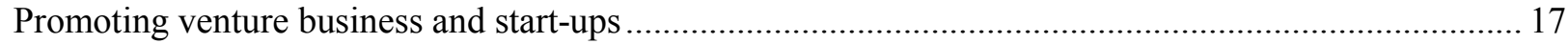

Spurring the development of Koreas venture capital market ............................................................ 17

The governments plan for a "creative economy" through enhancing the role of venture business ....... 20

Directions for reform to promote the venture business sector and new start-ups............................... 21

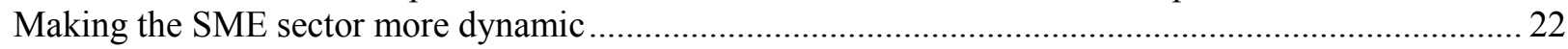

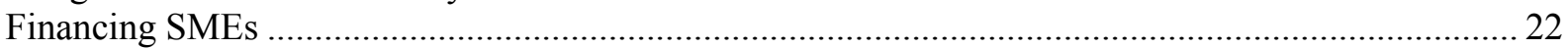

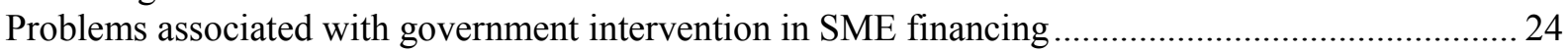

Make greater use of the Internet to make SMEs more efficient ........................................................ 28

Reducing labour mismatches: ensuring appropriate human capital for SMEs ................................... 29

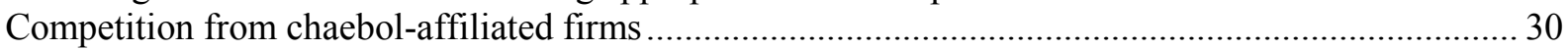

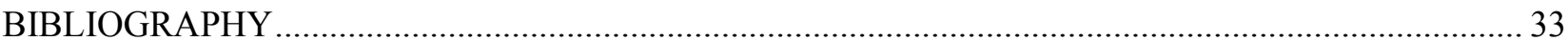

\section{Tables}

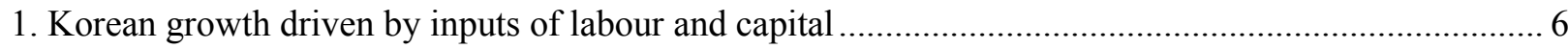

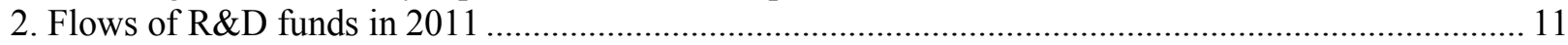

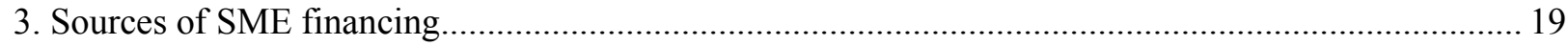

4. Central government programmes to support SMEs ……............................................................... 27

\section{Figures}

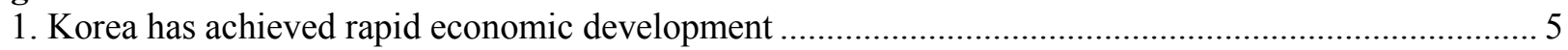

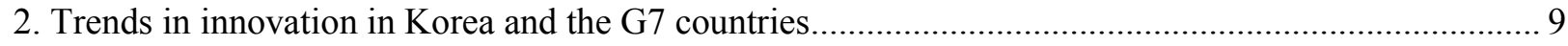

3. Total factor productivity growth and business R\&D intensity .......................................................... 9

4. Comparative performance of national science and innovation systems .............................................. 10

5. Government support for business-sector R\&D is high in Korea....................................................... 12

6. OECD countries differ in their ability to allocate labour to the most productive firms ....................... 14

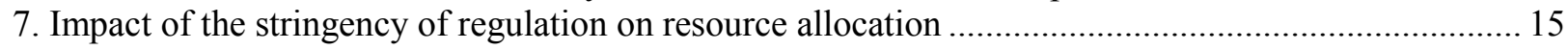

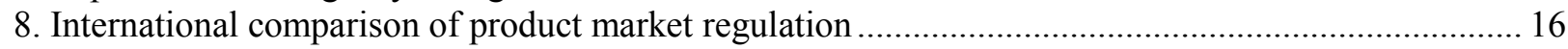

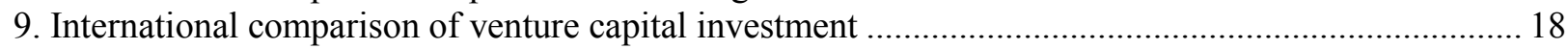

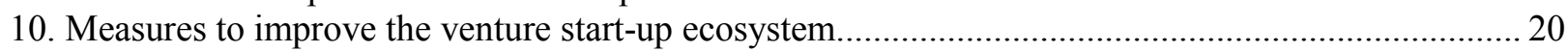

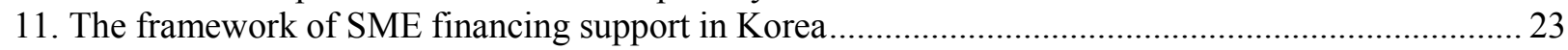

12. Korean SMEs account for a large share of banks' corporate lending .............................................. 24

13. The share of government financial support given to SMEs according to the age of the firm ............. 26

14. Share of companies that sell their goods and services on the Internet ............................................ 29

15. Korea has a high share of youth who are neither in employment nor in education or training........... 30

\section{Boxes}

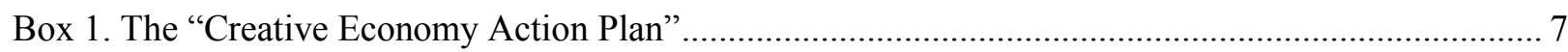

Box 2. Summary of recommendations to foster a creative economy ..................................................... 31 
ECO/WKP(2014)48

\title{
FOSTERING A CREATIVE ECONOMY TO DRIVE KOREAN GROWTH
}

\author{
By Randall S. Jones and Myungkyoo Kim ${ }^{l}$
}

Korea has grown from one of the poorest countries in the world in the 1950s to an advanced industrial economy today. Per capita income increased from 12\% of the US level in 1970 to $62 \%$ by 2011 (Figure 1). Development was driven by policies to promote exports, which were primarily produced by large companies, especially those in the business groups known as chaebols. However, as Korea has narrowed the gap with the most advanced economies, this growth model is facing challenges. Strong competition with emerging economies, notably China, in low and medium-end markets, and with advanced economies in high-end markets, is making it more difficult for Korea to further expand its global market share. In addition, the trickle-down effect from exports has declined. In 1998, 1 billion KRW of exports generated value-added of 0.65 billion KRW and 19 jobs. By 2010, the impact, adjusted for inflation, had fallen to 0.56 billion KRW of value-added and 7.9 jobs (Bank of Korea, 2012a), prompting the government to look for other sources of growth.

Figure 1. Korea has achieved rapid economic development

Korea's per capita income as a share of that in the United States ${ }^{1}$

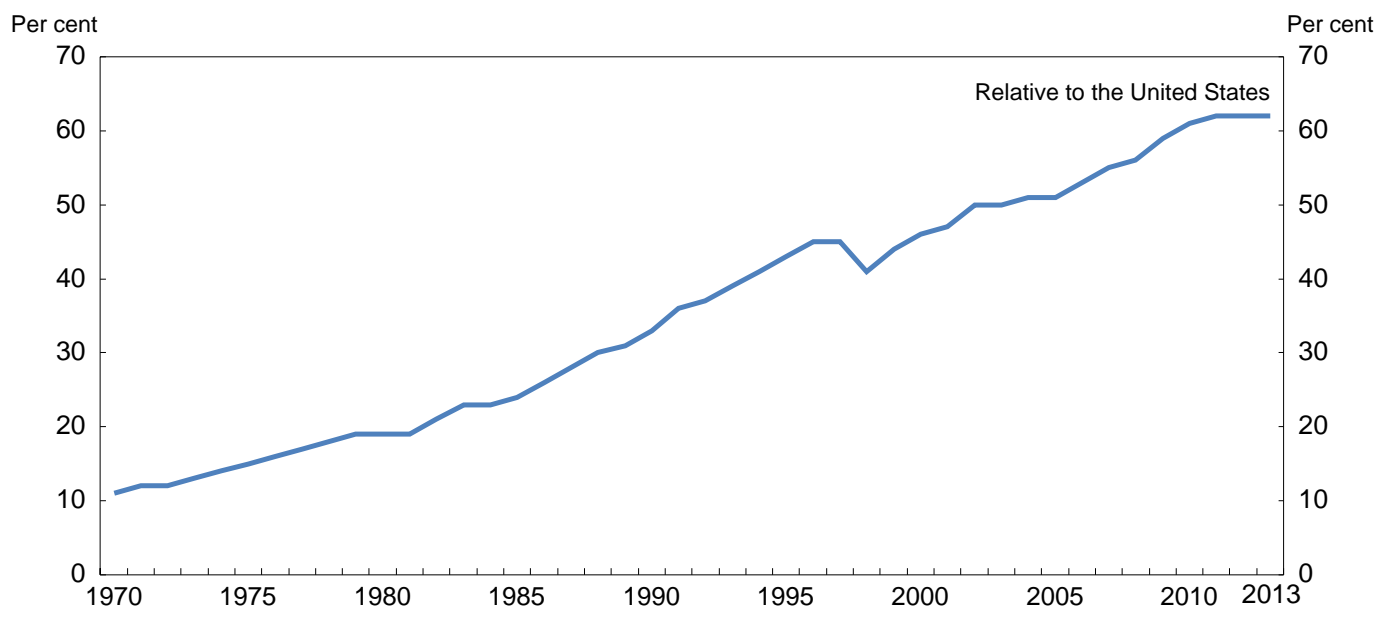

1. GDP per capita, converted at 2005 purchasing power parity exchange rates. The data for Korea are based on SNA1993, as SNA2008 data are not available prior to 2000, while those for the United States are based on SNA2008. Using SNA2008 for Korean GDP in 2013 would raise Korea per capita income from $62 \%$ of the US level to $68 \%$.

Source: OECD National Accounts Database.

1. Randall S. Jones is head of the Japan/Korea Desk in the OECD Economics Department and Myungkyoo Kim is an economist on that desk. This paper was originally produced for the 2014 OECD Economic Survey of Korea published in June 2014 under the authority of the Economic and Development Review Committee (EDRC) of the OECD. The authors would like to thank Dan Andrews, Andrew Dean, Robert Ford, Vincent Koen, Carlo Menon and Satoshi Urasawa, as well as officials from the government, for valuable discussions and comments on earlier drafts. Special thanks go to Lutécia Daniel for technical assistance and to Nadine Dufour and Mikel Inarritu for technical preparation. 
Korea's rapid development relied heavily on foreign technology (MOSF, 2013), accompanied by large inputs of labour and physical capital. Over the period 1970-2000, labour and capital contributed 4.3 percentage points to the $7.6 \%$ average annual increase in national income (Table 1). However, the contribution fell to 1.7 percentage points to an average growth rate of $4.6 \%$ over $2000-10$ and is likely to fall further as the working-age population begins shrinking in 2017 and working time continues to decline from its still high level. However, Korea has great potential to raise labour productivity per hour worked, which remains less than one-half of that in the United States. To sustain Korea's convergence to the highest income countries, it is therefore necessary to raise productivity through greater creativity and innovation. To meet this challenge, the government launched a blueprint to promote a "creative economy" by combining creativity with "science, technology and ICT to create new industries and markets, and to make existing industries stronger and thus create good jobs" (Box 1). The government also unveiled a three-year innovation plan at the end of February 2014 (2014 OECD Economic Survey of Korea).

Table 1. Korean growth driven by inputs of labour and capital

Contribution in percentage points

\begin{tabular}{lrcccc}
\hline & $1970-$ & $1970-1980$ & $1980-1990$ & $1990-2000$ & $2000-2010$ \\
& 2000 & & & & \\
\hline National income growth (\%) & $\mathbf{7 . 6}$ & $\mathbf{7 . 8}$ & $\mathbf{9 . 3}$ & $\mathbf{5 . 8}$ & $\mathbf{4 . 6}$ \\
Total inputs & $\mathbf{4 . 3}$ & $\mathbf{5 . 0}$ & $\mathbf{5 . 1}$ & $\mathbf{3 . 0}$ & $\mathbf{1 . 7}$ \\
Labour & 2.7 & 3.1 & 3.4 & 1.8 & 1.0 \\
Employment & 2.4 & 2.8 & 3.2 & 1.5 & 1.0 \\
Working-time $_{\text {Change in composition }}{ }^{1}$ & 0.1 & 0.4 & 0.0 & -0.3 & -0.7 \\
Education & 0.1 & 0.0 & 0.1 & 0.1 & 0.1 \\
Efficiency gains & 0.3 & 0.1 & 0.5 & 0.4 & 0.3 \\
Other & 0.0 & -0.1 & 0.0 & 0.2 & 0.2 \\
Capital & -0.1 & -0.1 & -0.4 & 0.0 & 0.0 \\
Productivity gains & 1.6 & 1.9 & 1.7 & 1.1 & 0.8 \\
Resource reallocation & $\mathbf{3 . 3}$ & $\mathbf{2 . 8}$ & $\mathbf{4 . 2}$ & $\mathbf{2 . 8}$ & $\mathbf{2 . 9}$ \\
$\quad$ Reduction in agriculture & 0.2 & 0.7 & 0.2 & -0.6 & 0.8 \\
$\quad$ Reduction in unpaid work & 0.2 & 0.2 & 0.2 & 0.2 & 0.1 \\
Economies of scale & -0.1 & 0.4 & -0.0 & -0.8 & 0.7 \\
Technical progress & 1.5 & 1.4 & 1.8 & 1.1 & 0.8 \\
\hline
\end{tabular}

1. Change in the gender and age composition of workers.

2. Increased efficiency due to shorter working hours.

Source: Kim et al. (2012).

A creative economy is underpinned by three building blocks (Andrews and Criscuolo, 2013), which are featured in the government's blueprint:

1. Investment in knowledge-based capital, such as computerised information, innovative intellectual property and economic competencies. The blueprint sets a goal of "creating an autonomous and challenging research environment" and "strengthening ICT innovation capacity" (Strategy 5).

2. The implementation and commercialisation of new ideas. The blueprint includes "supporting the commercialisation of research outcomes" (Strategy 5).

3. Realising the benefits of innovation through the reallocation of resources via rapid changes in market shares and profitability - so-called "creative destruction". The blueprint emphasises "creating conditions to easily start new businesses" (Strategy 1), "creating new industry based on software and the Internet" and promoting the creation of markets through regulatory reform (Strategy 3), and strengthening the entrepreneurial spirit (Strategy 4). 


\section{Box 1. The "Creative Economy Action Plan"}

The blueprint adopted by the Cabinet in June 2013 set three goals, six strategies and related tasks.

Goal 1: Create new jobs and markets through creativity and innovation.

Goal 2: Strengthen Korea's global leadership through a creative economy.

Goal 3: Create a society where creativity is respected and manifested.

The six strategies with their related tasks are:

1) Properly compensate for creativity and create an ecosystem that promotes the creation of startups:

- Create the conditions to easily start new businesses through investment, rather than bank financing.

- Patent creative ideas.

2) Strengthen the role of venture businesses and SMEs in the creative economy and their ability to enter global markets:

- The government and public institutions will become the largest customer to support the pioneering of new markets.

- $\quad$ Ease regulations and increase government support to stimulate investment.

- Achieve the goal of growth for start-ups by accessing global markets.

- Create an ecosystem that encourages co-operation and win-win relations between SMEs and large corporations.

- Construct a system that connects demand, education and recruitment to resolve human resource shortages.

3) Create growth engines to pioneer new markets and new industries:

- Combine science, technology and ICT to energise existing industries.

- Develop new industries based on software and the Internet.

- Create new markets through human-oriented technology innovation.

- Pioneer new markets by discovering and fostering new promising industries for the future.

- Promote market creation and industry convergence through rationalisation of regulation.

4) Foster global creative talent that has the spirit to rise to challenges and pursue dreams:

- Strengthen the development of creative convergence talent.

- Invigorate a challenging entrepreneurial spirit.

- Stimulate the overseas advancement and domestic inflow of creative talent.

5) Strengthen the innovation capacity of science, technology and ICT, which form the foundation for the creative economy:

- Create an autonomous and challenging research environment and support the commercialisation of research outcomes.

- Pioneer next-generation markets by strengthening ICT innovation capacity.

- Stimulate the regional economy and strengthen the commercialisation function and regional innovation of universities.

- Solve international social problems through Korean science, technology and ICT in order to raise Korea's status.

6) Promote a creative economic culture together with the Korean people:

- Develop a creative culture that realises creativity and imagination.

- $\quad$ Fuse Korean ideas with public resources through government 3.0. 
- Innovate government working methods in order to realise a creative economy.

- Centre the creative economy on the private sector, not the government.

Source: Ministry of Strategy and Finance (2013).

This paper addresses the challenges to implementing the blueprint, beginning with the innovation framework, which includes the first two building blocks of investment in knowledge-based capital and the implementation and commercialisation of new ideas. The second section considers framework conditions, such as product market regulation, foreign direct investment (FDI) and labour market flexibility, which play a key role in determining how quickly investment in innovation is transformed into economic growth. The government's objective of creating new industries and markets is addressed in the third section, which discusses policies to promote start-ups. This is a priority, given that new firms play a key role in commercialising new technology and creating jobs. At the same time, the blueprint's goal of strengthening existing industries requires boosting innovation and productivity in small and medium-sized enterprises (SMEs). The fourth section thus focuses on the difficulties that contribute to low productivity in SMEs such as obtaining financing, labour mismatches and the challenges posed by the chaebols. Policy recommendations are summarised at the end of the paper.

\section{An overview of Korea's innovation system}

Most of the income gaps between developed economies cannot be explained by the stock of labour and tangible capital resources, but instead depend on investment in knowledge-based capital (KBC), defined as innovative property, software and economic competencies (OECD, 2013h). The contribution of $\mathrm{KBC}$ depends on both the amount of investment and the returns to these investments. Korea's investment in $\mathrm{KBC}$ amounted to $6.6 \%$ of GDP in $2008^{2}$ (Chun et al., 2012), which would place it slightly above the average of 26 other OECD countries (Corrado et al., 2012).

Korea's performance in KBC is underpinned by R\&D spending that reached $4.4 \%$ of GDP in 2012 , the highest in the OECD area. Moreover, the business sector accounts for three-quarters of the outlays, one of the highest shares in the OECD area. Business R\&D is particularly important as it has the greatest impact on multifactor productivity growth (Westmore, 2013). Korea's business R\&D spending has risen $35 \%$ in real terms since 2008, in contrast to the G7 countries, where it was more severely affected by the global crisis (Figure 2). Strong business R\&D supported patent filings, which rose by $32 \%$ during the same period, an increase matched only by Japan among the G7 (Panel B). Consequently, Korea's share of world patent filings reached $5.7 \%$ in 2011, up from 2.3\% in 2003 (OECD, 2012b). Korea's post-crisis performance suggests a dynamic and resilient innovation framework.

\section{The return on investment in innovation could be increased by improving the innovation system}

Korea's total factor productivity (TFP) grew at an annual average rate of 1.1\% over 1995-2011 (Figure 3). Business R\&D has been closely linked to productivity performance (Westmore, 2013). Some countries, such as Australia, Austria, Germany, Ireland and the United States, have achieved TFP growth rates comparable to Korea's with lower business R\&D intensity, suggesting scope to improve the efficiency of Korea's innovation system. The high level of R\&D spending could be translated into faster TFP growth by upgrading the quality of universities and strengthening their links with firms, expanding international collaboration in innovation, ensuring adequate human capital in science and engineering and improving the framework for public support for R\&D.

2. All comparisons in this chapter using GDP are based on SNA1993, which provides time series data back to 1970, rather than on SNA2008, which was released in late March 2014 for the period 2000-13. 
Figure 2. Trends in innovation in Korea and the G7 countries
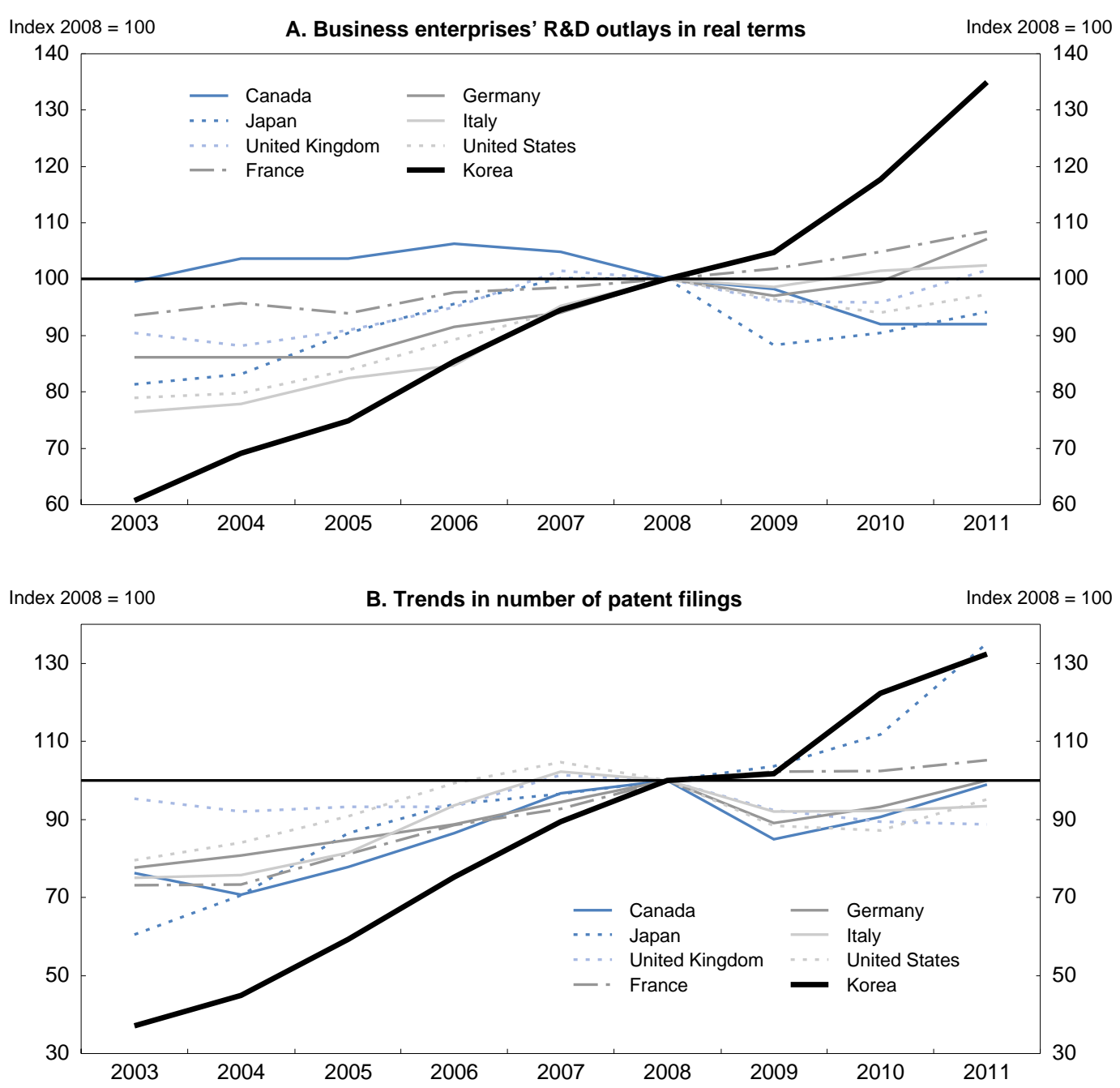

Source: OECD (2014c).

Figure 3. Total factor productivity growth and business R\&D intensity 1995-2011

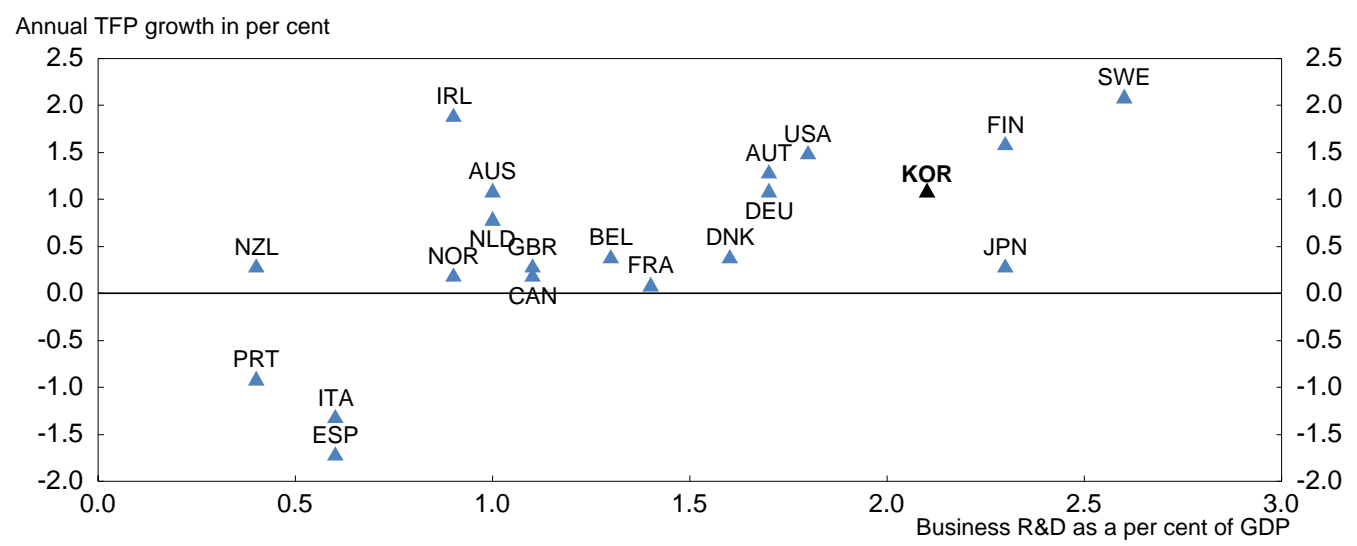

Source: OECD Analytical Database; OECD Long-term Scenario Database; and OECD (2014c). 


\section{Upgrading the quality of universities and strengthening their links with firms}

The rapid expansion in Korea's university system has come at some expense to quality (OECD, 2009). The share of high school graduates advancing to tertiary education climbed from $33 \%$ in 1990 to a peak of $84 \%$ in 2008 , before falling to $71 \%$ in 2010 . Total spending at the tertiary level in Korea was $2.6 \%$ of GDP in 2010, one of the highest in the OECD. Nevertheless, the number of Korean universities ranked in the top 500 (relative to GDP) was well below the OECD median in 2011 (Figure 4, Panel A).

Figure 4. Comparative performance of national science and innovation systems

$\ln 2011$
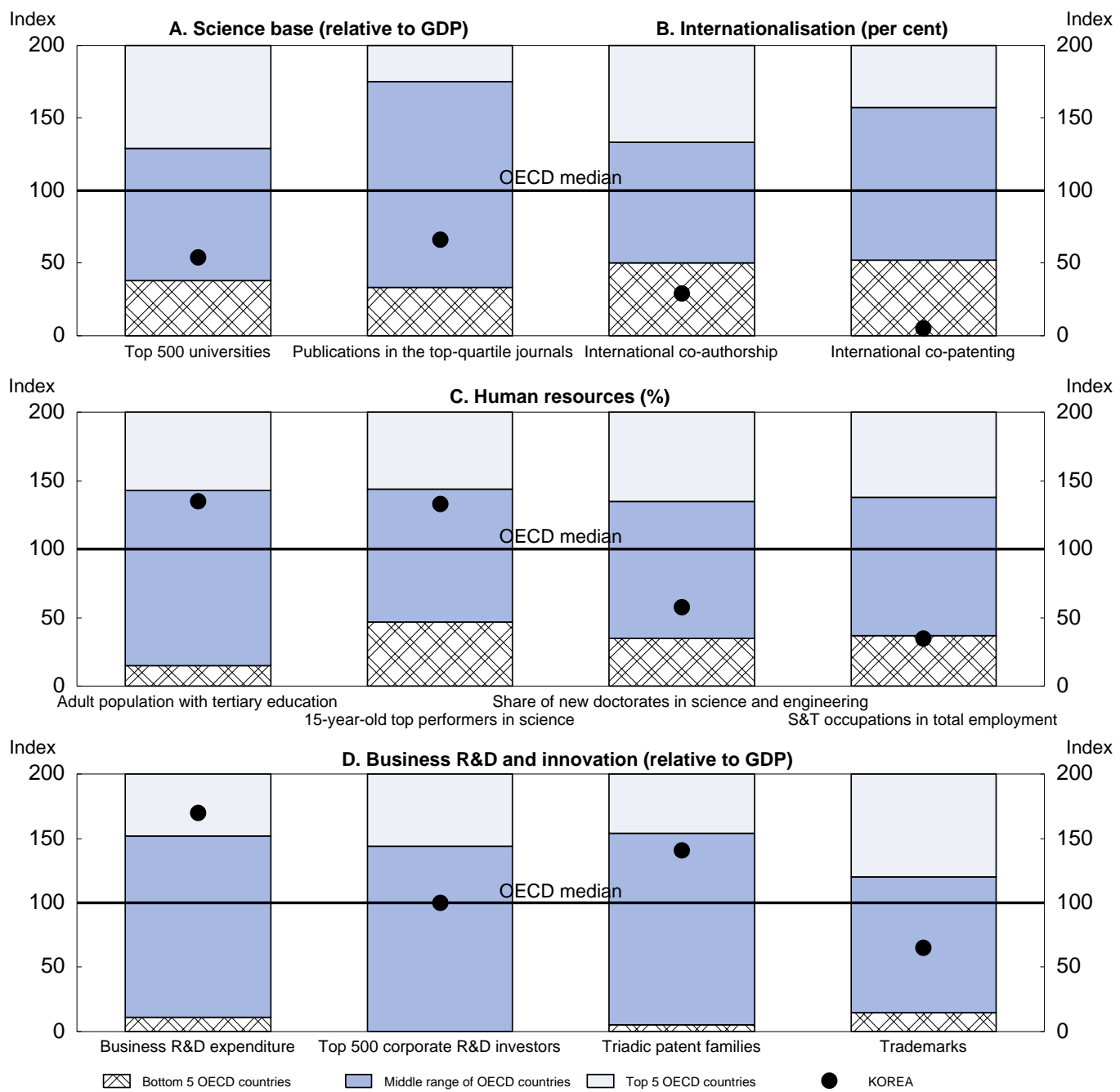

Note: Normalised index of performance relative to the median values in the OECD, which are set at 100 . The top performer is set at 200 and the lowest at zero. The figure shows the range of scores received by the top five and bottom five performers. For example, the fifth-highest performer in the case of the "Top 500 universities" had a score of 129 relative to the OECD median, while the fifth lowest had a score of 38 . Korea, with a score of 54 , was in the middle range.

Source: OECD Main Science and Technology Indicators Database.

Korea has too many tertiary institutions and those outside of Seoul struggle to fill their student quotas (OECD, 2009). Most institutions run operating deficits and the situation is likely to deteriorate as demographic projections suggest that the number of high school graduates will fall below the current admission quotas for tertiary institutions by 2020 . It is essential, therefore, to consolidate the university 
sector while raising quality. First, it is necessary to reduce public funding to poorly performing universities and ensure a well-functioning accreditation system to promote consolidation. Second, the top-down system of university regulation should be relaxed to encourage autonomy, innovation and flexibility (Jones, 2013).

Upgrading universities should include R\&D performance. While universities employ around threequarters of PhDs in Korea, they performed only 10\% of R\&D in 2010, about half of the OECD average. Meanwhile, $97.3 \%$ of the R\&D financed by enterprises was performed in the business sector, compared to only $1.5 \%$ at universities (Table 2), suggesting a lack of trust between businesses and universities. As a result, only $5 \%$ of company patents cite university-developed technology, compared to around $9 \%$ in Canada and the United States (OECD, 2014a). Increased emphasis on research at universities should be accompanied by greater university-business co-operation in a range of areas, including accreditation and curriculum (Jones, 2013). A greater university role in R\&D would also enhance basic research, which is becoming more important as Korea approaches the technology frontier in many fields.

Table 2. Flows of R\&D funds in 2011

\begin{tabular}{lc|cccc}
\hline & \multicolumn{4}{c}{ Allocation between R\&D actors $^{1}$} \\
\cline { 2 - 6 } & $\begin{array}{c}\text { Share of total R\&D } \\
\text { spending }\end{array}$ & Government & Universities & $\begin{array}{c}\text { Business } \\
\text { enterprises }\end{array}$ & Total \\
\hline Business enterprises & 73.7 & 1.2 & 1.5 & 97.3 & 100.0 \\
Government & 24.9 & 49.0 & 32.6 & 18.4 & 100.0 \\
Universities & 0.7 & 3.7 & 92.2 & 4.1 & 100.0 \\
Non-profit institutes & 0.4 & 53.7 & 42.8 & 3.6 & 100.0 \\
Foreign sources & 0.2 & 39.2 & 17.8 & 43.1 & 100.0 \\
\hline
\end{tabular}

1. By which sector performs the R\&D.

Source: OECD R\&D Statistics Database.

\section{Ensuring adequate human capital in science and engineering}

Korea is well known for its educational achievements. The share of the adult population with a tertiary education is above the OECD median (Figure 4, Panel C), and will rise toward the top, given that $64 \%$ of young adults (25 to 34 ) have completed tertiary education, the highest in the OECD. Among 15year-olds, Korea was near the top in science in the 2012 PISA tests (OECD, 2013g) and the proportion of its top performers is well above the OECD average. However, this outstanding performance does not translate into tertiary education and the labour market. Indeed, the share of science and engineering in new doctoral degrees and the share of science and technology (S\&T) occupations in total employment are well below the OECD median (Figure 4, Panel C). Only 63\% of tertiary graduates in natural sciences in 2006 found jobs, compared to $67 \%$ for all graduates, and only $60 \%$ found jobs in their field of study, compared to $69 \%$ for all graduates (OECD, 2007). The low share of S\&T workers reduces the absorptive capacity of firms to benefit from knowledge spillovers, thus limiting the returns from innovative activity (Westmore, 2013).

\section{Expanding international collaboration in research and patenting}

Internationalising the university sector would improve its quality and expand international collaboration in innovation. Korea has relatively few overseas students and a near absence of foreign higher education institutions. The share of foreign students in tertiary education in Korea in 2009 was $1.6 \%$, well below the $8.7 \%$ OECD average. However, five foreign universities have established branch campuses in Korea, with three approved during 2013-14. Moreover, the number of foreign students increased by 15 times over 2000-09. Greater internationalisation of universities would increase the share of international co-authorship and co-patenting, which are both among the lowest five in OECD countries (Figure 4, Panel B). Only $0.2 \%$ of the R\&D carried out in Korea in 2012 was financed from abroad 
(Table 2), linkages with foreign firms and institutions are relatively weak, and few foreign researchers come to Korea. This impedes Korea's ability to draw on the global stock of knowledge. The low level of international collaboration is linked to the low degree of openness to trade and investment (see below).

\section{Improving the framework for public support for $R \& D$}

Public support for business-sector R\&D is justified by market failures that keep R\&D spending below the socially-optimal level. Government support in Korea, which is the highest in the OECD as a share of GDP, is evenly divided between tax incentives, a non-discriminatory tool that reduces the marginal cost of R\&D for firms, and direct support, such as grants, loans and loan guarantees to specific firms (Figure 5). Tax incentives have been found to encourage R\&D: according to an OECD study, a $6 \%$ increase in the generosity of R\&D tax incentives boosts the level of R\&D by about $6 \%$ in the long run. However, the impact is less if $R \& D$ tax policy changes frequently, indicating the importance of a predictable policy framework. In addition, direct government support has a positive impact on private-sector R\&D, as a 10\% rise boosts private R\&D outlays by $5 \%$ (Westmore, 2013).

Korea's balanced approach to supporting $R \& D$ appears appropriate, although both $R \& D$ tax credits and direct payments may have unintended negative consequences. In particular, R\&D tax credits favour large companies because they pay a higher corporate tax rate $(24.2 \%)$ than SMEs $(11 \%)$, and in any case, many small firms do not pay any corporate income tax at all. The larger benefits to large companies disadvantage new, more productive firms (Bravo-Biosca et al., 2012). Consequently, more generous R\&D tax credits are associated with a higher share of stagnant firms and a lower share of growing firms (Andrews and Criscuolo, 2013). The negative impact is partially mitigated in Korea by allowing the tax credit to be carried over for up to five years, thus allowing new firms, which typically record losses, to benefit from the tax credit if they subsequently make profits. Providing cash refunds of tax credits, as is done in some OECD countries, would provide more assistance to younger firms.

Figure 5. Government support for business-sector R\&D is high in Korea

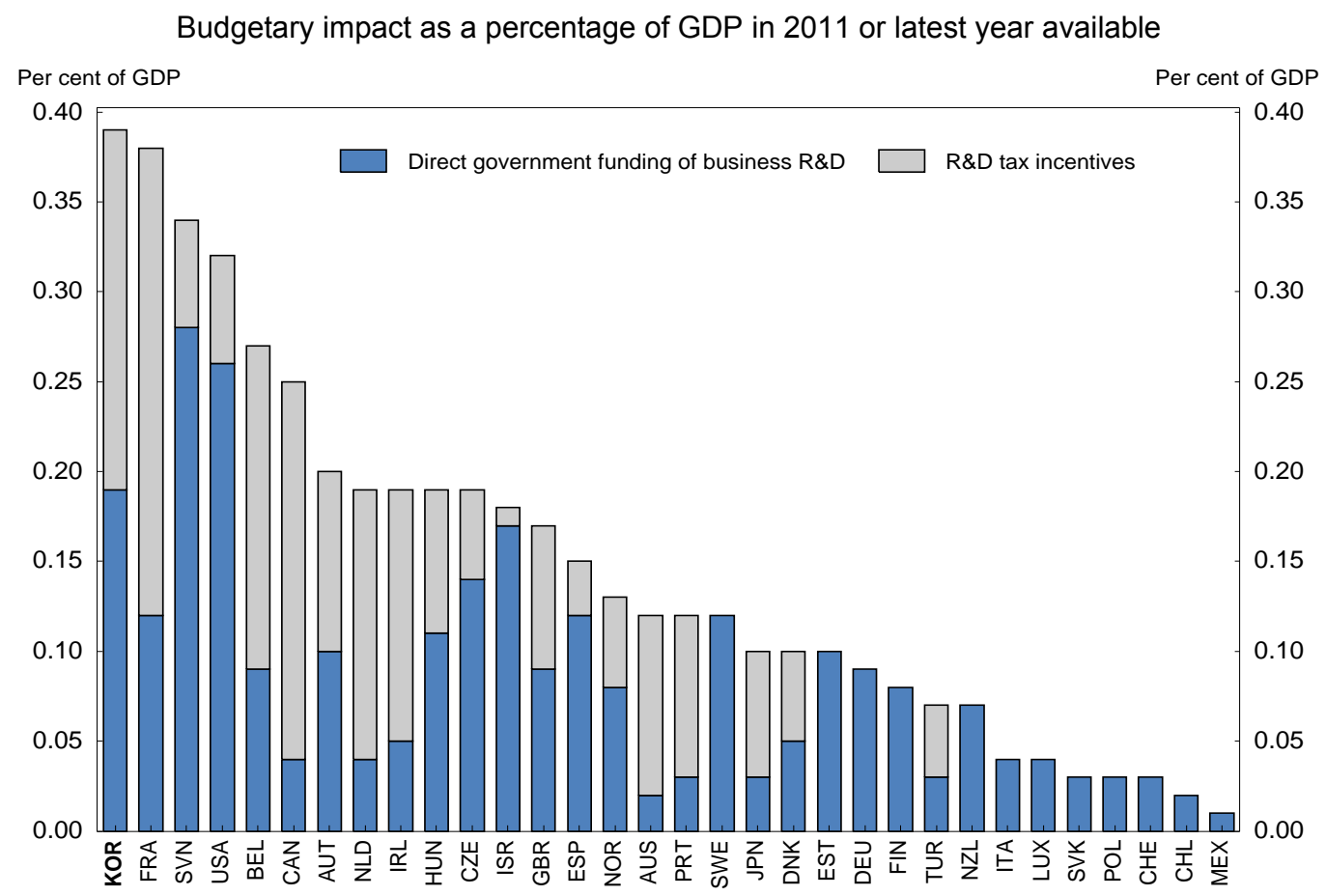

Source: OECD (2013f). 
While direct support for $\mathrm{R} \& \mathrm{D}$ has a more neutral impact on incumbents vis-à-vis new entrants, it creates the risks associated with "picking winners". Given this risk, direct R\&D support in the OECD area has fallen in recent decades. To prevent wasteful outlays, the allocation of direct support should be based on a competitive, objective and transparent selection process. While this increases administrative and compliance costs, subsidies allocated on a selective basis tend to have a larger impact on firm productivity than automatic subsidies (Colombo et al., 2011), in part because a careful evaluation process sends a quality signal to private firms receiving public R\&D support (Kleer, 2010). In Korea, 13 ministries run R\&D programmes, each with their own selection process. In the case of the Ministry of Science, ICT and Future Planning, the Ministry selects the area for R\&D but leaves the selection of firms to experts. Finally, it is essential to constantly evaluate the effectiveness of $R \& D$ policies to ensure good value for money.

Another challenge is to raise the quality of R\&D conducted in government research institutes (GRIs). In 2011, there were 41619 government-funded R\&D projects, with total spending exceeding $1 \%$ of GDP. Of the total, more than one-third went to the 27 GRIs, whose performance has been criticised (OECD, 2014a). GRIs have failed to meet expectations of the private sector, which has greatly expanded its R\&D capabilities. It is important to clearly define the role of GRIs, improve their steering and incentives and enhance co-operation between GRIs, universities and corporate research labs. GRIs may have a role to play with SMEs where R\&D is low. Firms with less than 250 workers accounted for only $24 \%$ of total business R\&D, compared to the OECD average of $33 \%$ (OECD, 2013f). In addition, there may be a role for them to play in services, which accounted for only $9 \%$ of business R\&D in 2011, well below the OECD average of $38 \%$.

\section{Framework conditions to promote a creative economy}

As noted above, cross-country differences in productivity and growth are due in part to the returns on investment in $\mathrm{KBC}$, which in turn depend on a reallocation of resources in favour of innovative firms. If the market works, those that fail to adopt the most productive technologies have to downsize or exit, thereby releasing resources to more efficient firms. Productivity and output growth are maximised when productive resources flow toward innovating firms. The ability to rapidly reallocate labour and capital is particularly important in innovative sectors so that firms can capture the value of their ideas before imitation by competitors (Andrews and de Serres, 2012). On the other hand, frictions in the reallocation of labour and capital lower the expected net benefits of innovation. Likewise, in the event of technological failure, it is vital that firms in innovative sectors can rapidly scale down operations to release resources to other firms. By raising the return on investment in $\mathrm{KBC}$, flexibility in resource allocation also raises the amount of such investment (Andrews and Criscuolo, 2013).

Allocative efficiency in Korea is low, based on a measure that shows the extent to which the most productive firms have larger employment shares (Figure 6). A score of zero means that labour is allocated randomly. By this measure, the actual allocation of employment boosts manufacturing labour productivity in most OECD countries. In the United States, the actual distribution of workers boosts labour productivity by around $50 \%$ above what it would be if workers were distributed randomly (Andrews and Cingano, 2012). However, in Korea, more productive firms tend to have slightly less labour than if labour were allocated randomly, suggesting weakness in resource allocation. This section considers three policy areas product market regulation, foreign competition and labour mobility - that influence allocative efficiency. SME policies, which also have a major impact, are discussed in a later section. 
Figure 6. OECD countries differ in their ability to allocate labour to the most productive firms

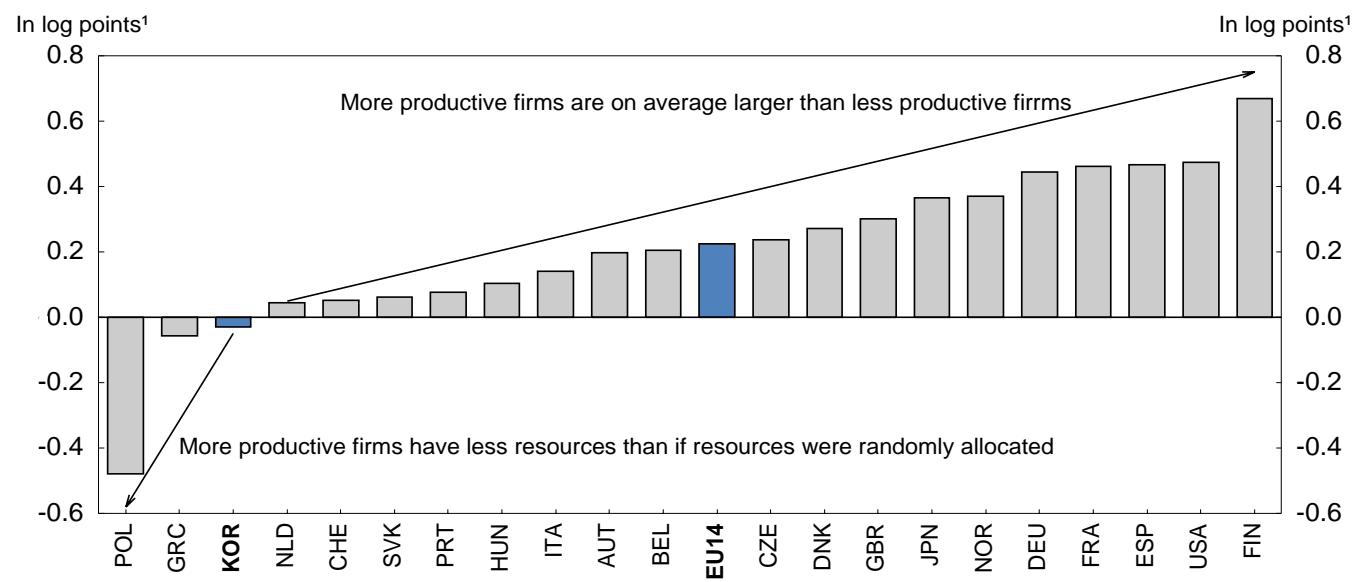

1. The covariance across firms between firm size in terms of the numbers of employees and labour productivity in manufacturing in 2005. If a country's covariance (a measure of the extent that the two variables change together) is positive, the allocation of employment boosts labour productivity.

Source: OECD (2013d).

\section{Product market regulation and innovation}

Empirical studies show a significant relationship between product market regulations (PMR) and productivity at the aggregate level (Bouis et al., 2011), reflecting the pervasive impact of PMRs at each stage of the innovation process. Less restrictive PMRs promote: i) private investment in innovative activities; ${ }^{3}$ ii) the effective diffusion of knowledge from both domestic and overseas sources (Westmore, $2013)$; iii) improved managerial performance; and iv) entry by new firms, thus increasing the supply of new ideas.

Less restrictive regulations also enable firms to attract the complementary resources that are needed to implement and commercialise new ideas. For a firm that experienced a $10 \%$ increase in patents over $2002-10$, it is estimated that its work force increased by between $0.7 \%$ and $2.4 \%$ depending on the strictness of product market regulation (Figure 7). In turn, greater allocative efficiency results in faster productivity and output gains. In contrast, higher PMRs stifle innovation and economic growth. For example, an increase in PMRs is found to have a direct negative impact on patenting activity. ${ }^{4}$ One study found that convergence to the frontier will be slower for countries with higher PMRs (Westmore, 2013).

Korea's overall PMR indicator was 1.9 in both 2008 and 2013, the second highest in the OECD, while the OECD average fell from 1.5 to 1.4 over that period (Figure 8). In terms of barriers to entrepreneurship, Korea recorded a small decline from 2.0 to 1.9 (Panel B). Nevertheless, it failed to narrow the gap with the OECD average, which fell from 1.8 to 1.5 over the same period. Further efforts to eliminate unneeded product market regulation should be an essential element of Korea's strategy to foster the development of a creative economy, as stated in Strategy 3 of the Creative Economy Action Plan (Box 1) and in the Threeyear Plan for Economic Innovation (2014 OECD Economic Survey of Korea).

3. New OECD research shows that a modest cut in the PMR in the energy, transport and communications sectors - corresponding to the difference in regulation between Australia and Austria in 2008 - could boost the level of business R\&D by $5 \%$ and patents per capita by $3 \%$ in the long run (Westmore, 2013).

4. A hypothetical reduction in regulation in Finland in 2008 equivalent to the PMR indicator falling to the sample average in that year (a decline of 0.35 ) is estimated to result in a $3 \%$ rise in patents per capita. 
Figure 7. Impact of the stringency of regulation on resource allocation

For a firm with a $10 \%$ increase in its patent stock over 2002-10 1
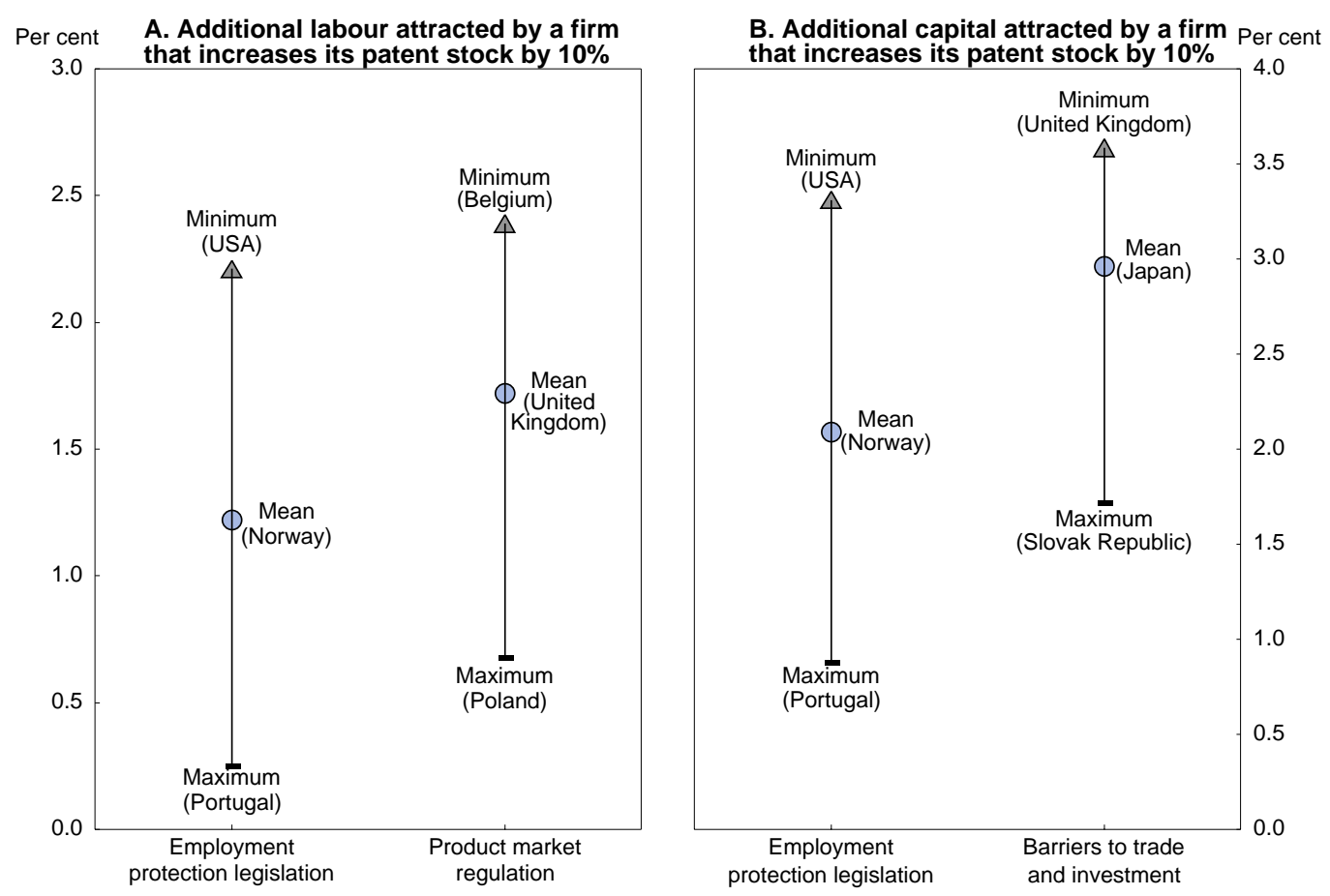

1. For each category of regulation, "minimum" refers to the country that is least restrictive (for example, Belgium in the case of PMR), while "maximum" refers to the country that is most restrictive.

Source: Andrews et al. (2014).

\section{Promoting international competition}

The liberalisation of barriers to international trade and investment broadens the scope for knowledge diffusion and technological transfer across borders, either embodied in goods and services or through investment that transmits ideas. International openness also encourages more efficient resource allocation; firms that cannot compete in the global market downsize, while those that can, expand production. The increase in the capital stock in a firm that experienced a $10 \%$ increase in patents ranged from $1.7 \%$ to $3.6 \%$ depending on the strictness of trade and investment barriers (Figure 7). Countries that are open to trade and investment can benefit more from foreign R\&D and new technologies, production processes and organisational methods, spurring domestic innovation (Jaumotte and Pain, 2005). These benefits are maximised by pro-competition PMRs, which intensify incentives for firms to incorporate foreign technologies.

Korea has pursued trade liberalisation through free trade agreements, notably with the European Union (2011), the United States (2012), Canada (2014) and Australia (2014). Nevertheless, its index of barriers to trade and investment was the highest in the OECD area in 2013 (Figure 8, Panel C), helping to explain why Korea has the third lowest stock of FDI in the OECD area, at 13\% of GDP in 2012. In addition to explicit barriers, the low stock reflects the business environment and other domestic restrictions, making regulatory reform a key to attracting more FDI. 
Figure 8. International comparison of product market regulation ${ }^{1}$
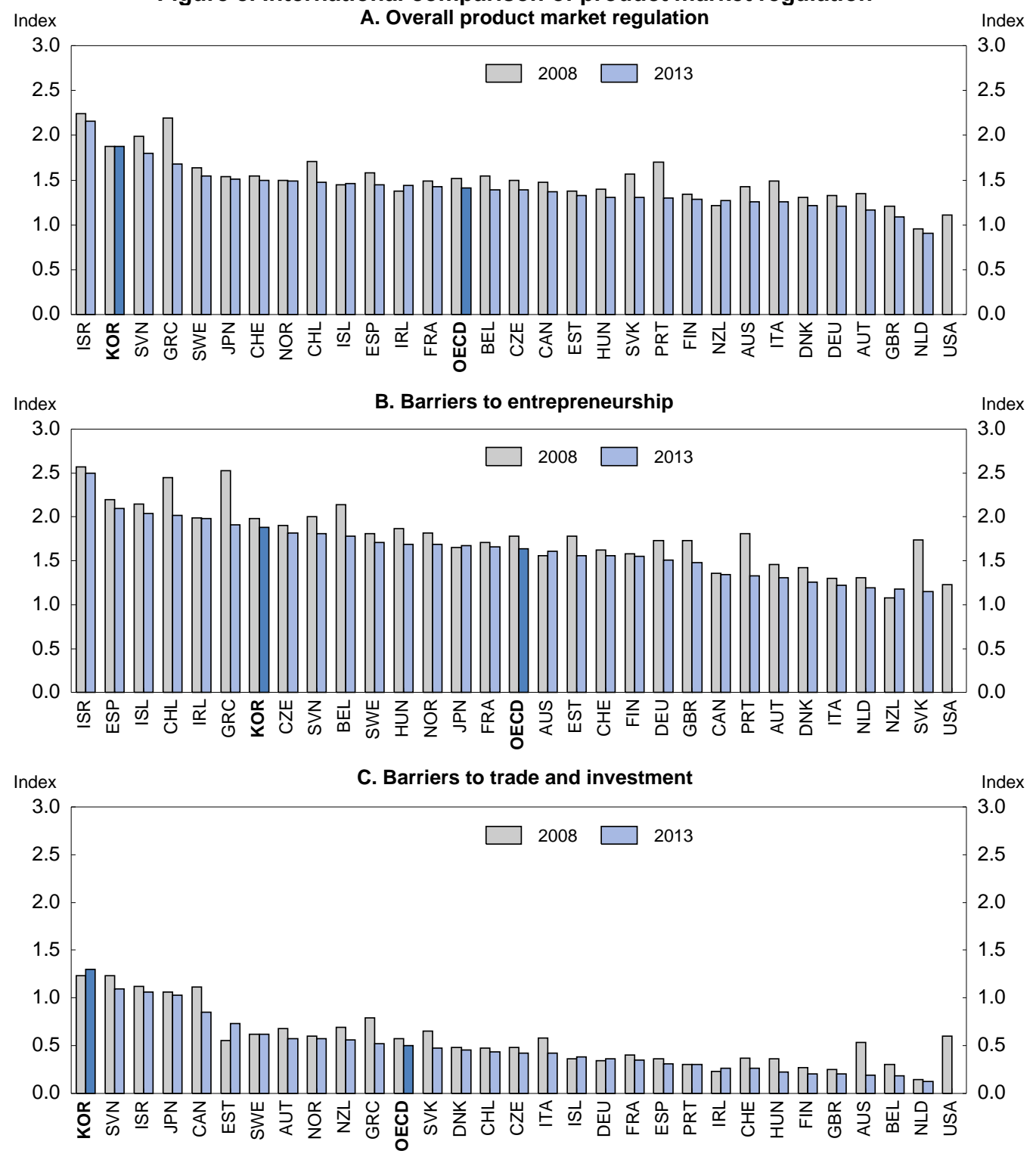

1. The OECD Indicators of Product Market Regulation are a comprehensive and internationally-comparable set of indicators that measure the degree to which policies promote or inhibit competition. Empirical research shows that the indicators have a robust link to performance. The indicator, which ranges from zero (most relaxed) to three (most stringent), is available for 30 OECD countries. The overall indicator is based on more than 700 questions.

Source: OECD Product Market Regulation Database and Koske et al. (2014).

\section{Labour market flexibility: relaxing employment protection}

Innovation requires continuous reallocation of labour and other resources within and across firms and sectors. There is considerable evidence that employment protection has a major impact on labour flows (Martin and Scarpetta, 2012). Low levels of protection allow resources to flow to their most productive uses, benefiting firms that undertake innovations that require large employment adjustments. But high employment protection has negative impacts on innovation: 
- It reduces R\&D expenditure, particularly in innovative sectors (Andrews and Criscuolo, 2013). Firms in industries characterised by rapid technological change place a high value on flexibility, given their tendency to experiment with uncertain technologies. By raising exit costs, stringent employment protection makes experimentation less attractive.

- It reduces the ability of innovative firms to attract the resources needed to implement and commercialise new ideas. The increase in the work force in a firm that experienced a $10 \%$ increase in patents ranged from $0.3 \%$ and $2.2 \%$ depending on the strictness of employment protection, while the increase in capital ranged from $0.9 \%$ to $3.3 \%$ (Figure 7). Moreover, the negative effect of employment protection falls disproportionately on young firms.

High employment protection thus hinders resource reallocation, weakening productivity growth, particularly in firms in ICT-intensive sectors and those close to the technology frontier (Andrews and Criscuolo, 2013). Employment protection also hinders venture capital financing in innovative sectors, which rely on the rapid reallocation of resources across the investment portfolio from failing to successful ventures. Finally, multinational enterprises tend to concentrate more technologically-advanced innovation in countries with low employment protection, thus making resource shifts easier.

In Korea, employment protection has been a factor in the rise in the share of non-regular workers (such as fixed-term, dispatched and part-time workers) to around one-third of employment (2014 OECD Economic Survey of Korea). Indeed, the share of temporary workers was the fourth highest in the OECD in 2012. According to surveys, firms hire non-regular workers in part to enhance employment flexibility and avoid the cost of laying off regular workers, who receive high employment protection as a result of government policies, business practices, social customs and labour unions (Koh et al., 2010). Relaxing employment protection would benefit Korea by increasing investment in R\&D in innovative sectors and enabling innovative firms to attract the resources necessary to commercialise new ideas, thereby promoting higher productivity and output growth. In addition, reducing the reliance on temporary employment would encourage firm-based training and human capital accumulation, which would enhance innovation.

\section{Promoting venture business and start-ups}

Successful innovative start-ups play an important role in mature economies. Firms that drive one technological wave often fail to participate in subsequent waves. Instead, young firms often have a comparative advantage in commercialising radical innovations. Firms less than five years old, regardless of their size, accounted for less than a fifth of total non-financial business employment but generated half of all new jobs over 2001-11 (OECD, 2013f). The success of Korea's strategy to promote a creative economy depends to a large extent on raising the rate of business creation and the role of fast-growing young firms.

\section{Spurring the development of Korea's venture capital market}

The major challenge is financing start-ups, giving their limited internal funds, short history and lack of tangible collateral. The financing gap can be bridged by venture capitalists and business angels who are willing to accept high risk for high returns. Such investors address the information asymmetries by intensively scrutinising new firms before providing capital and monitoring them afterwards. In Korea, the government jump-started the venture capital market in 1998 through a direct infusion of equity capital, generous tax incentives and credit guarantees. The government's objective then, as it is today, was to accelerate business restructuring and shift the economy from chaebols to start-ups in knowledge-based industries. However, these policies fuelled a bubble in the Korea Securities Dealers Automated Quotation (KOSDAQ), the secondary stock market. With the collapse of the IT bubble, the KOSDAQ experienced a $90 \%$ decline from its peak. The venture capital market contracted by a quarter over 2002-06. 
However, Korea's venture capital market has rebounded steadily since 2006, with paid-in capital more than doubling by 2013 despite the 2008 crisis. The total number of firms with venture investment on their balance sheets has been on an upward trend since 2009, although it remains below its level in the early 2000s. ${ }^{5}$ In 2012, venture capital investment reached $0.1 \%$ of GDP (on a flow basis), the third highest among OECD countries for which data are available (Figure 9).

Figure 9. International comparison of venture capital investment

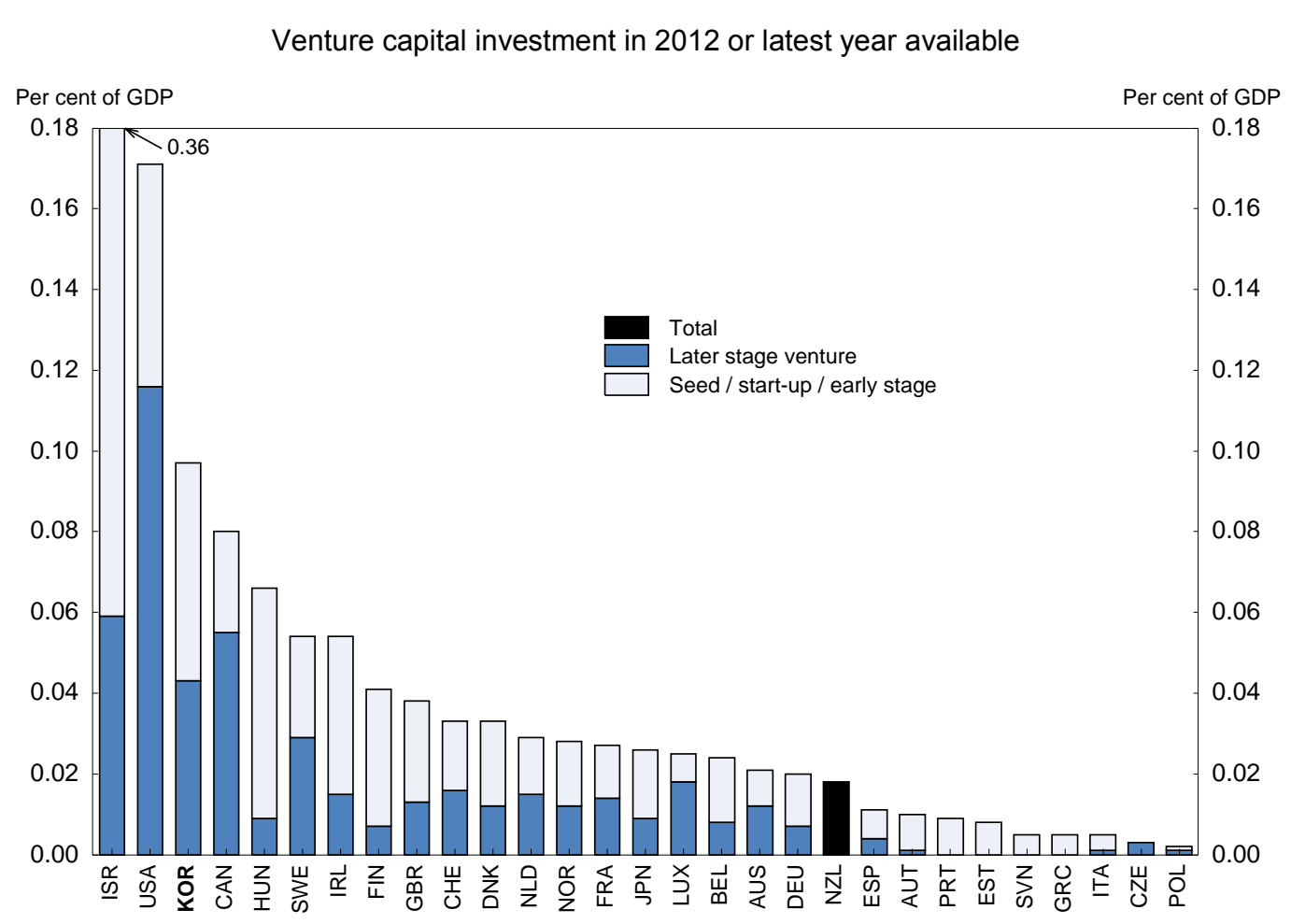

Source: OECD (2013b).

Despite its recovery and relatively large size, the venture capital market accounted for less than $1 \%$ of SME financing in 2011 (Table 3). Moreover, it faces a number of weaknesses, including a M\&A market that is underdeveloped compared to other OECD countries (OECD, 2014a), constraining the ability of venture capitalists to realise returns from their investment. Indeed, the share of venture capitalists' earnings that are realised from M\&As was only 7\% in 2011 compared to $69 \%$ in the United States, ${ }^{6}$ in part due to cultural factors in Korea, where M\&A activity has long been associated with bankruptcy proceedings. Consequently, venture capitalists have to turn to initial public offerings (IPOs) in the KOSDAQ, although this is complicated for start-ups due to demanding requirements, including maintaining a high profitability rate. Indeed, the average net profit ratio of newly-listed companies in KOSDAQ ranged from $11 \%$ to $16 \%$ over 2008-12, making it two to three times higher than the $5 \%$ average of all listed companies (MOSF et al., 2013). Consequently, it takes a long time for a start-up to meet the criteria for an IPO. On

5. The number of firms classified as venture businesses by the government increased more than threefold from around 9 thousand in 2000 to nearly 29 thousand in 2012. In contrast to some countries, a Korean firm that does not receive investment from a venture capitalist can still be designated as a venture business by spending more than $5 \%$ of sales on R\&D or having its technology certified by the government.

6. This compares earnings from M\&As as a share of earnings from IPOs and M\&As combined (Korea Venture Capital Association, 2013). 
average, it takes more than 14 years for start-ups to be listed on KOSDAQ, far exceeding the lifespan of most venture capital funds. Indeed, only 78 of 393 funds in 2010 were more than six years old (Yang et al., 2013).

Table 3. Sources of SME financing

As a per cent of the total ${ }^{1}$

\begin{tabular}{c|c|c|c|c|c|c|c}
\hline Year & Banks & Non-banks & $\begin{array}{c}\text { Bonds and } \\
\text { equities }\end{array}$ & $\begin{array}{c}\text { Venture } \\
\text { investment }\end{array}$ & $\begin{array}{c}\text { Government } \\
\text { guarantees }\end{array}$ & $\begin{array}{c}\text { Other } \\
\text { government }\end{array}$ & Total \\
\hline 2004 & 61.1 & 22.7 & 0.6 & 1.2 & 13.6 & 0.8 & 100.0 \\
2006 & 64.0 & 22.7 & 0.8 & 0.8 & 11.0 & 0.7 & 100.0 \\
2008 & 68.0 & 21.0 & 0.8 & 0.7 & 8.9 & 0.6 & 100.0 \\
2009 & 64.7 & 21.0 & 1.0 & 0.7 & 11.7 & 1.0 & 100.0 \\
2010 & 64.5 & 20.7 & 0.7 & 0.8 & 12.3 & 1.1 & 100.0 \\
2011 & 67.8 & 17.2 & 0.5 & 0.9 & 12.3 & 1.4 & 100.0 \\
\hline
\end{tabular}

1. Government guarantees are assumed to cover bank lending. Some of the lending by government institutions is reported as loans by banks and non-banks.

Source: Sohn and Kim (2013).

As a result, venture capital funds tend to invest in relatively mature companies rather than in firms at an earlier stage when such funding is most critical. Indeed, $55 \%$ of firms receiving venture capital investment were older than three years and $27 \%$ were more than seven years old. Moreover, the share of venture capital investment in firms younger than three years fell from $40 \%$ in 2008 to $28 \%$ in 2012 , reflecting institutional weaknesses.

There are a number of other weaknesses in the venture capital sector:

- The number of individual investors in the market, the so-called business angels, fell sharply from nearly 29 thousand prior to the collapse of the ICT bubble to only 4870 in 2013 . This is an impediment to a vibrant venture business sector, as the angels play an important role in mentoring start-ups and providing networking, in addition to their financing role.

- The narrow and shallow venture capital market thus depends heavily on the government, which risks crowding out private investors. Public funds accounted for 33\% of venture funds in 2012, with an additional 12\% share for public pension funds (MOSF et al., 2013).

- While the government has emphasised support to the supply side of the venture capital market, the availability of high-quality projects appears to be the key constraint (OECD, 2014a). Indeed, the experience of other countries shows that the development of the venture capital industry has followed, rather than preceded, the availability of attractive opportunities. ${ }^{7}$

- Re-investment by venture entrepreneurs who have already achieved success is relatively small for a number of reasons related to the tax system and financial market practices. ${ }^{8}$

7. The Korea Venture Capital Association has stated that it is becoming increasingly hard to find good investment opportunities in Korea, leading some of its members to establish operations overseas, particularly in China and Vietnam (OECD, 2014a). In addition, there are complaints that in Korea the most talented individuals work at chaebols rather than becoming entrepreneurs.

8. For example, when shares are sold at more than $30 \%$ above the market price, the sale is subject to the $50 \%$ maximum gift tax instead of the 11\% capital gain tax. Such high tax rates limit the scope for re-investing gains in the venture capital market. 


\section{The government's plan for a "creative economy" through enhancing the role of venture business}

The government launched a plan in May 2013 (Figure 10) that aims to: i) promote angel investment and introduce crowd-funding, which is a collective effort by individuals who pool their resources, usually through social networking via the Internet, to invest in new projects; ii) develop the market for M\&As involving venture businesses and business angels; and iii) encourage reinvestment by both successful and failed entrepreneurs. ${ }^{9}$

Figure 10. Measures to improve the venture start-up ecosystem

The government's May 2013 plan

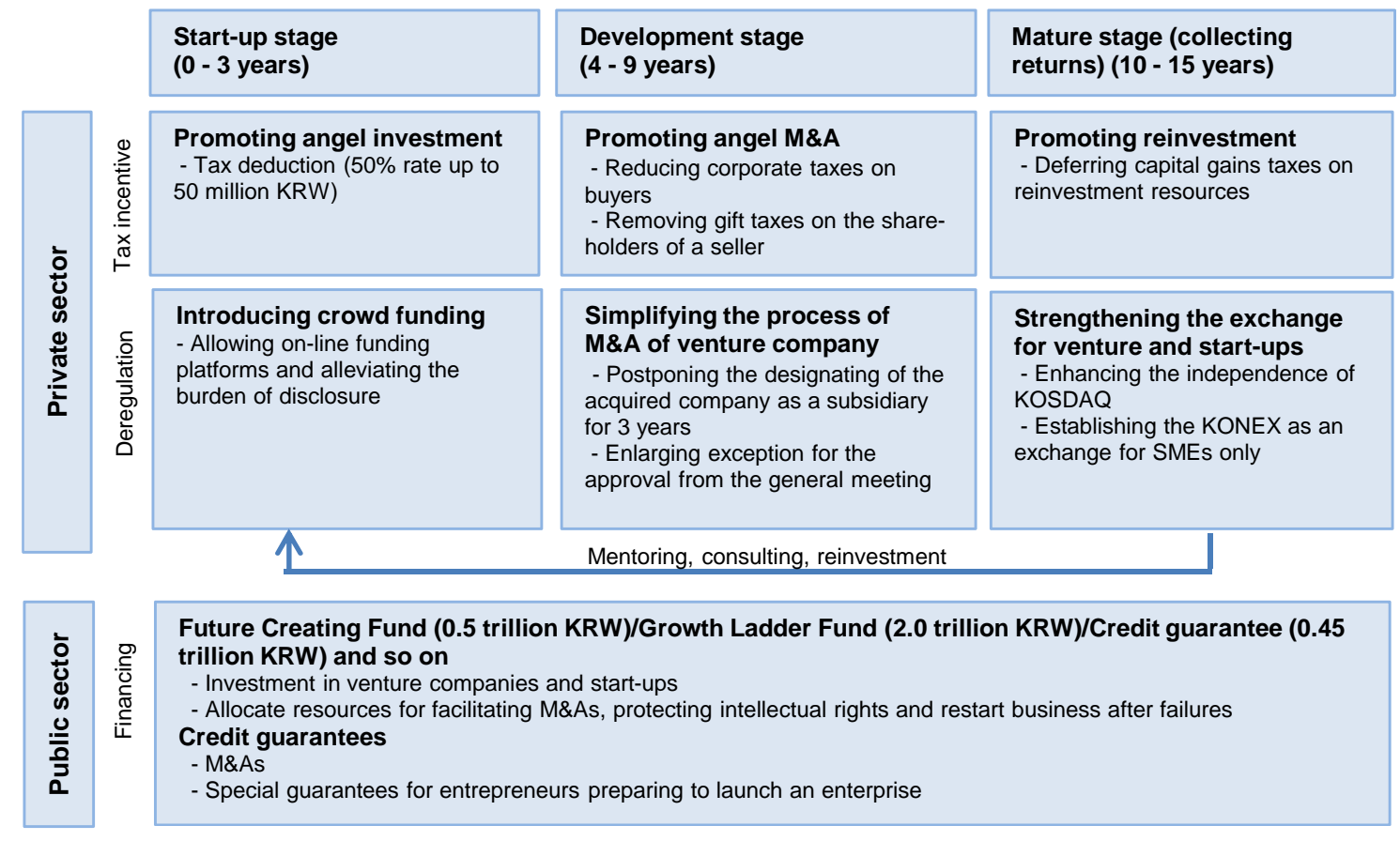

Source: MOSF et al. (2013).

Increased investment by business angels is to be achieved through more generous tax incentives. This is meant to be part of an overall shift from loans to investment-based financing for ventures and start-ups, reflecting the critical importance of risk sharing between entrepreneurs and financial institutions during the first few years of a firm's existence. The government also launched the Future Creation Fund, partially funded with the private sector, to finance venture business, with a share reserved for start-ups.

Regulations related to M\&As are also evolving. For example, when the merger of two SMEs creates a firm too large to be classified as an SME, the new entity can nevertheless maintain the legal status of a SME for three years, thereby continuing to receive preferential treatment. In addition, the government will provide financial support for M\&As involving venture businesses through the Growth Ladder Fund and public guarantees for M\&As relying on private financing.

9. The Fund for the Next Venture Generation will promote reinvestment by successful entrepreneurs, while the Restart Support Fund will support entrepreneurs who have failed. Details on government programmes to promote venture business are provided in Jones and Kim (2014). 
The Korea New Exchange (KONEX) was established in 2013 to ease the difficulties of start-ups younger than three years by relaxing the requirements for listing and disclosure. ${ }^{10}$ For example, the number of mandatory disclosure items was set at 29 compared to 64 in KOSDAQ. Meanwhile, KOSDAQ, which was originally created to support venture businesses, will be made more accessible to start-ups. In 2012, only 21 new companies were listed in KOSDAQ, compared to 171 in 2001, reflecting its focus on investor protection (MOSF et al., 2013). KOSDAQ's management is being changed and the requirements for an IPO are being relaxed while not significantly reducing investor protection.

The government is also taking measures to expand and improve the infrastructure for venture businesses and start-ups. First, in 2013, the government launched a start-up platform, a type of crowd sourcing that allows entrepreneurs to propose ideas that are then voted on by the on-line community. Second, government research institutes are being encouraged to co-operate with venture businesses and to establish firms using their own technology and ideas. Third, visas will be granted to foreigners willing to start a business in Korea. Although the visas are for only two years, they can be renewed if foreigners continue doing business in Korea. ${ }^{11}$ Fourth, the government will also improve protection for SMEs' technology by expanding the "Intellectual Property Rights Fund", which buys patents and technology from small firms and then licenses the rights back to them. The advantage is that the Fund is better at fighting piracy than small firms. ${ }^{12}$

Finally, the insolvency framework has been improved, increasing opportunities for entrepreneurs to try again. In particular, the practice of "joint liability", which required a firm requesting loans from financial institutions to obtain an agreement from a co-guarantor - typically the company owner or his relatives - was prohibited for banks in 2012 and for non-bank financial institutions in 2013. Joint liability had increased the cost of bankruptcy by making entrepreneurs personally delinquent, leading to their exclusion from financial markets.

\section{Directions for reform to promote the venture business sector and new start-ups}

The success of the government's comprehensive plan to develop venture business depends on overcoming traditional social norms. For example, the stigma attached to bankruptcy limits second chances for failed entrepreneurs and the negative perception of M\&As restricts financing options. The plan combines public funds with structural reforms in an effort to create a new environment. One of the biggest challenges is to shift from bank-centred finance to greater reliance on investment-based financing, which depends in part on the success of KONEX as an exchange for start-ups. The sound development of KONEX requires correctly balancing investor protection and market dynamism. Excessive investor protection would make the market unattractive to companies and investors alike, while inadequate protection would raise risks of moral hazard, illegal activities by listed companies and an asset price bubble. Venture business also depends on the M\&A market, hence the government's plans to jump start it through the provision of public funds and guarantees.

It is important to avoid an excessive supply of public funds relative to the number of high-quality projects, as they would tend to crowd out private investment. In order to avoid a repeat of the KOSDAQ

10. KONEX is aimed at smaller companies, requiring firms to meet only one of three listing conditions: i) sales revenue of more than 1 billion KRW (\$963 thousand); ii) capital of more than 0.5 billion KRW; or iii) profits of more than 0.3 billion KRW.

11. Moreover, start-up visa holders who stay in Korea for three years or more, attract investment of at least 300 million KRW (\$289 thousand) and hire two or more Korean citizens are eligible for permanent residency.

12. In addition, the "Technology Deposit Safe" system, which allows SMEs to store technologically-valuable items in public institutions, will be expanded. 
collapse, it is important to make sure that money goes to firms that truly qualify as venture businesses. Providing public money through a "fund-of-funds" approach, in which the government invests in private venture capital firms rather than directly in start-up firms, has been identified as good practice internationally (OECD, 2014a). Public funds should be focused on early-stage financing where it is most difficult to attract private-sector investors.

Success in revitalising venture business also depends on reversing the sharp decline in the number of business angels, who bring funding, expertise and networks. The increased tax incentives should be accompanied by support to develop their quality and skills (Lerner, 2012). At the same time, there seems to be too much money (including public funds) chasing too few high-quality projects. A number of countries are shifting the focus of their venture programmes to enhance the quality of the investment projects proposed by venture businesses. Enhancing venture business also requires overcoming the social preference for working at chaebols rather than taking the risk of entrepreneurship. Indeed, only $34 \%$ of the population have a favourable image of entrepreneurs, well below the $49 \%$ OECD average (OECD, 2013b). Government efforts to create an environment that allows entrepreneurs who experience "honest failure" to have additional opportunities to create new ventures should help make entrepreneurship more attractive.

Korea should proceed cautiously with its plan to introduce crowd-funding. By 2011, an estimated $\$ 1.5$ billion has been raised worldwide through 700 platforms, even though the legal and institutional framework is still in its initial stages. The key concern is investor protection. In contrast to business angels, who have expertise and spend considerable time and money on due diligence before investing, crowdfunding relies on the general public, raising the risk of fraud (Isenberg, 2012). From a company perspective, relying on equity crowd-funding would mean losing the guidance and networks provided by seasoned angel investors. In addition, an idea launched via the Internet is easily copied.

\section{Making the SME sector more dynamic}

SMEs, which in the manufacturing sector are defined as firms with less than 300 employees or capital of less than 8 billion KRW (about $\$ 7.7$ million), accounted for $99.9 \%$ of registered firms in Korea in 2011, which is typical in OECD countries, and $87 \%$ of employment. ${ }^{13}$ The government provides large-scale support through public funds, credit guarantees and around 1300 SME programmes. Nevertheless, labour productivity in SMEs fell from 33\% of that in large companies in 2000 to $28 \%$ by 2011 (SMBA, 2013). At that point, wages in SMEs were only half of those in large companies. About one-third of SMEs have an interest-coverage ratio of less than $100 \%$, meaning that their earnings (before interest and taxes) are insufficient to cover their interest payments. Small SMEs, defined as firms with annual sales of less than 10 billion KRW (\$9.6 million), have had negative operating profits as a group since 2006 (Bank of Korea, 2012b). The problems in the SME sector are linked to the weakness of services, given that SMEs account for $91 \%$ of employment in that sector. In 2012 , service sector productivity was only $45 \%$ of that in manufacturing, far below the OECD average of $86 \%$.

\section{Financing SMEs}

Small firms' access to credit is constrained by their lack of collateral, short credit history and limited expertise in producing financial statements. Lending to SMEs is more risky, as information about small firms is costly to obtain and less reliable than for large companies. Nevertheless, lending to SMEs in Korea has risen sharply, reflecting structural changes in financial markets following the 1997 crisis and changes in government policies.

13. However, their share of employment falls to $37 \%$ if firms with less than ten employees are excluded. 
In 1997, commercial bank loans to large companies exceeded those to SMEs. However, loans to SMEs increased from $13 \%$ of GDP in 1997 to $42 \%$ by 2009 , before declining somewhat to $36 \%$. This was due in part to reduced demand from large companies, which emphasised deleveraging in the wake of the 1997 crisis. Indeed, the top 30 chaebols' debt-to-equity ratio fell from $500 \%$ at the end of 1997 to $118 \%$ by 2005. In addition, large firms were able to increase direct financing through capital markets, in contrast to SMEs. Consequently, loans to large firms in 2012 were 12\% of GDP, down from 16\% in 1997.

The government plays a key role in SME financing through a number of channels:

- It provides loans through public financial institutions (Figure 11), such as the Korea Finance Corporation (KFC) and the Small and Medium Business Corporation (SMBC). Loans can be provided directly to SMEs or through "on-lending" in which the KFC provides $40 \%$ of the loan amount to financial institutions, which are responsible for the remainder. On-lending is more efficient as it utilises the knowledge and experience of financial institutions (KDI et al., 2011). Total SME lending during 2011 by the KFC and the SMBC amounted to 11.8 trillion KRW (BAI, 2012), equivalent to $85 \%$ of the increase in the stock of loans to SMEs that year.

Figure 11. The framework of SME financing support in Korea

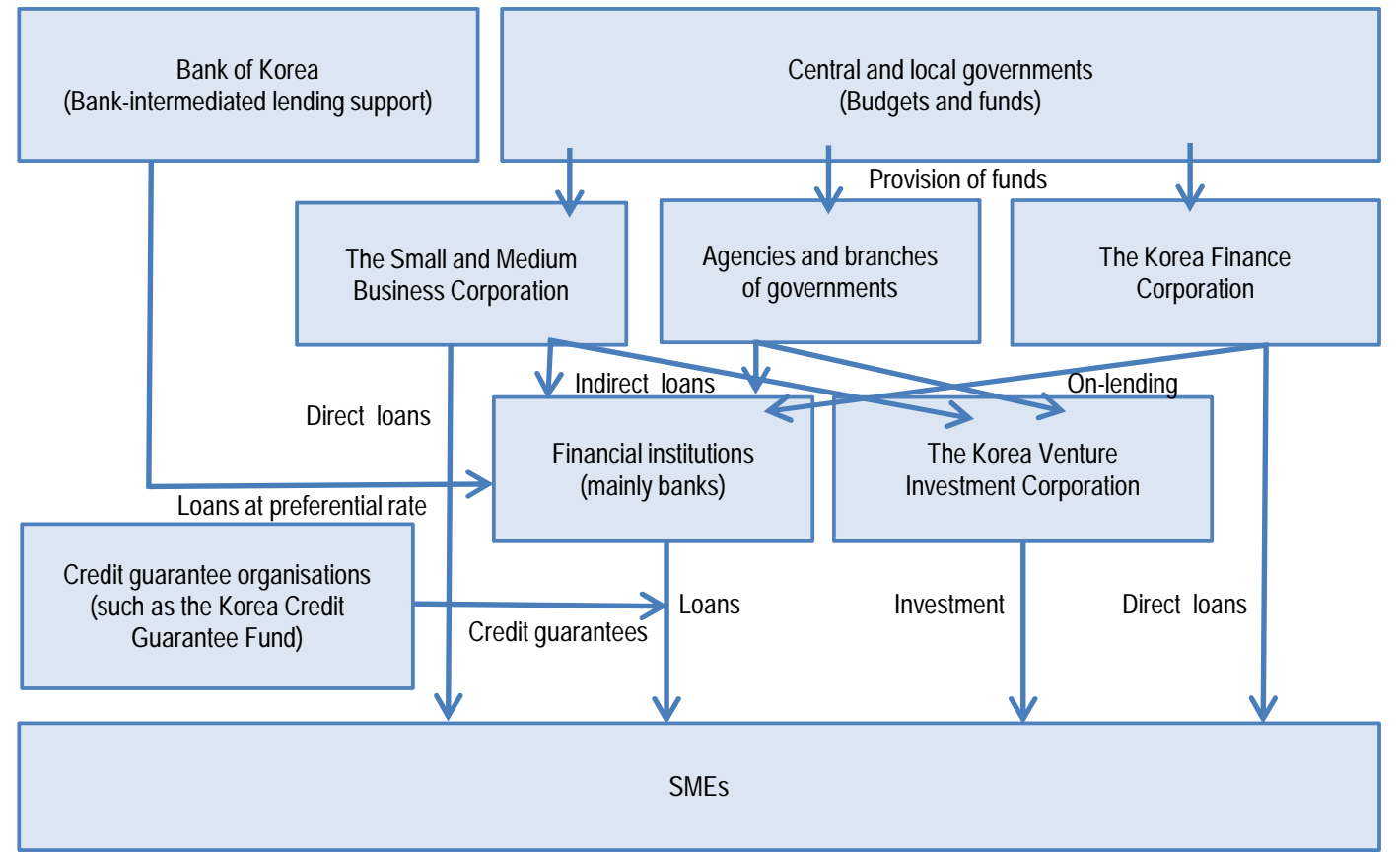

Source: The Board of Audit and Inspection (2012).

- The largest instrument of public support is credit guarantees, which promote loans to SMEs by reducing lenders' exposure to risk. Over 2007-11, public support in the form of credit guarantees amounted to 100 trillion KRW ( $8 \%$ of 2011 GDP) compared to 42 trillion KRW of direct lending (BAI, 2012) ${ }^{14}$ Credit guarantees covered $12 \%$ of bank lending to SMEs in 2011 , well above the

14. Guarantees are provided through the Korea Credit Guarantee Fund (KCGF), the Korea Technology Finance Corporation (KOTEC) and 16 Local Credit Guarantee Foundations established by the government and controlled by it. For more information, see Jones and Kim (2014). 
5\% OECD average (OECD, 2013c). Following the 2008 crisis, the limit on individual credit guarantees was raised from 3 billion KRW to 10 billion KRW (\$9.6 million) and the ceiling on the coverage of guarantees from $85 \%$ of the loan amount to $100 \%$.

- The Bank of Korea also encourages SME lending through its Bank-Intermediated Lending Support Facility, which provides funds to banks at preferential rates subject to certain conditions. To receive the full amount of funds available under this scheme, nationwide banks must allocate more than $45 \%$ of their new loans to SMEs (more than $60 \%$ in the case of local banks). Since August 2013, the scheme's base rate has been between $0.5 \%$ and $1.0 \%$ per year, well below the central bank's policy rate of $2.5 \%$. Such policy-based lending schemes raise concerns about resource allocation.

- The government promotes SME financing through moral suasion on financial institutions. For example, in the wake of the 2008 financial crisis, it asked banks to roll over SME loans automatically to prevent the default of sound SMEs.

As a result of structural changes in the financial market and public support, SMEs accounted for $78 \%$ of banks' corporate lending in 2012, one of the highest shares in the OECD (Figure 12). In principle, the level of public financing support for SMEs should depend on the financing gap, i.e. the difference between the amount of SME financing that would occur in the absence of market failures and the actual amount of financing, although this is difficult to calculate in practice (OECD, 2006). However, the focus of SME policies in Korea has expanded from correcting market failures to enhancing social cohesion, overcoming economic crises and promoting new growth engines (KDI et al., 2011). Finally, the share of direct financing through equities and bonds has remained low at only $0.5 \%$ in 2011 (Table 3).

Figure 12. Korean SMEs account for a large share of banks' corporate lending

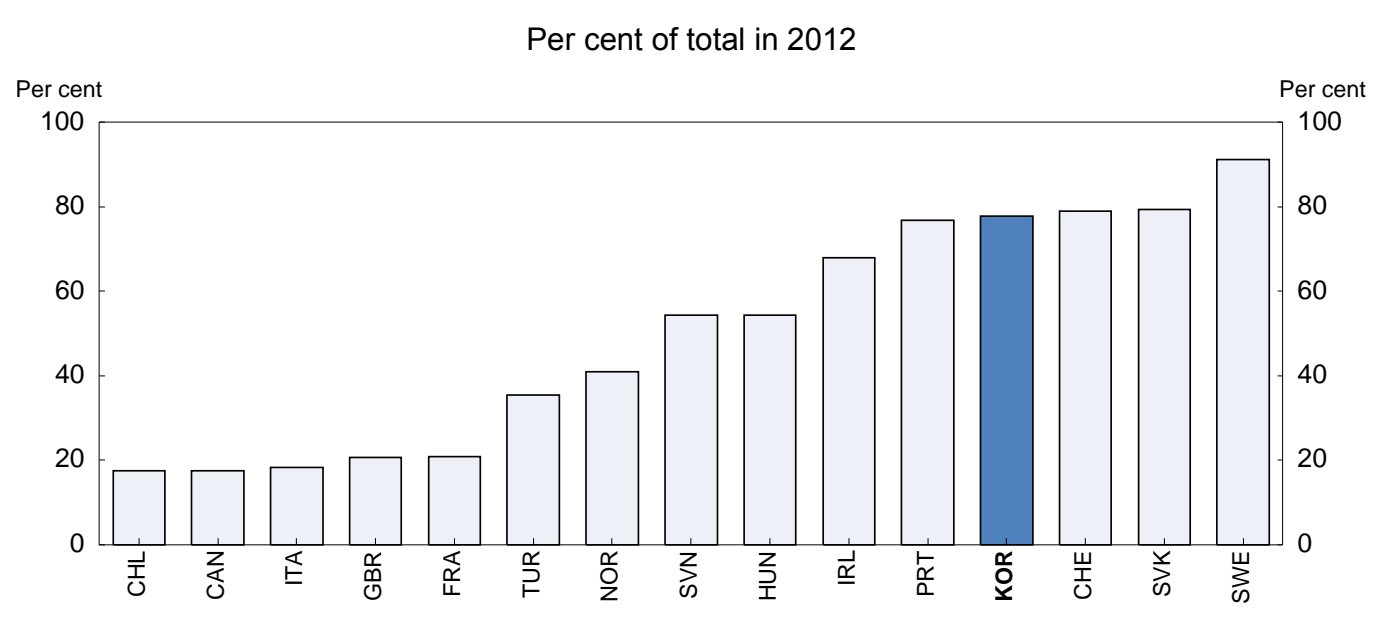

Source: OECD (2013c).

\section{Problems associated with government intervention in SME financing}

While in general terms, government support for SMEs is justified by market failures, it can also have negative side effects. First, the government's large role in SME financing in terms of providing direct credit and guarantees hinders the development of the market (Sohn and Kim, 2013). Financial institutions are content to enjoy stable profits at low risk thanks to government credit guarantees, thus reducing incentives to develop their credit evaluation and risk management skills for SME lending. Most lending to smaller firms is still made on the basis of collateral or credit guarantees provided by the government. The share of "pure credit loans" - loans from private financial institutions that are not guaranteed by a public institution or collateralised - was $21 \%$ of lending to SMEs in manufacturing in 2012, although that is a 
marked rise from the $7 \%$ in 2000 . SMEs also have an incentive to rely on government loans, which are easier to obtain and carry lower interest rates than loans by financial institutions. Indeed, the interest rate on SMBC loans for SMEs was 3.6\% in late 2013 compared to the market interest rate of $4.8 \%$. Such a gap discourages borrowing from financial institutions, thus slowing the development of a private SME financing market.

Second, government intervention often supports non-viable SMEs. Once loans are given to such a firm, financial institutions and credit guarantee providers share a common interest in its survival, as a default would result in losses for both of them. To delay or prevent such a loss, they may continue to support the firm, a phenomenon referred to as "evergreening". SME policies have been criticised for extending the life of non-viable companies in Korea and thereby reducing the country's growth potential (Kim and Koo, 2010). A Bank of Korea study of 1381 SMEs with an interest-coverage ratio below 100\% over $2000-02$ found that $27 \%$ had achieved a ratio of at least $100 \%$ by 2010 while $10 \%$ went out of business. Consequently, a majority of the firms (63\%) had somehow survived for a decade despite failing to earn enough income to cover their interest payments (Bank of Korea, 2012b). Another study of 1200 listed firms found that $17 \%$ of SMEs had an interest-coverage ratio of less than $100 \%$ for three years in a row compared to $8 \%$ of big companies (Noh and Lee, 2013). The policies introduced to assist SMEs after the 2008 crisis appear to have exacerbated the problem of non-viable companies. Despite the slowdown in GDP growth to $3.7 \%$ in 2011, the number of bankruptcies was only about half of that in 2007. Korea was one of only four OECD countries in which bankruptcies were lower in 2011 than in 2007 (OECD, 2013c).

The long-term survival of non-viable SMEs is facilitated by public financial support for mature firms. Although the market failure rationale for public support to SMEs suggests that assistance should be targeted at young firms, about half of government loans and credit guarantees in 2013 from Korea Credit Guarantee Fund (KCGF) and the Korea Technology Finance Corporation (KOTEC) went to companies that were more than ten years old (Figure 13). In contrast, only $20 \%$ of support was for firms created during the past five years. Moreover, the share of support to firms more than ten years old rose between 2006 and 2013. The average age of SMEs receiving assistance from public institutions is around nine years (KDI et al., 2011). In addition, the market-failure rationale for SME support also implies that the length of public support should be relatively short. Lending based on public guarantees should create a relationship between financial institutions and firms that overcomes the information asymmetry and eliminates the need for such guarantees (OECD, 2013c). However, in Korea, a significant share of public support is long term, thereby helping to prop up weak companies. As of 2011, 11\% of the credit guarantees from the KCGF and KOTEC had been given to the same firm for more than ten years.

Third, a notable aspect of Korea's corporate landscape is the relatively small number of middle-sized companies. Of the several million SMEs (i.e. firms with less than 300 employees) in 2002, only 696 had expanded into mid-sized companies (defined as 300 to 999 workers) by 2012 (Statistics Korea, 2013). The low number of firms that exit the SME category, the so-called "Peter Pan syndrome", reflects the generosity and long duration of government support, as well the abrupt end to such support once companies graduate from SME status. In addition to the $1300 \mathrm{SME}$ programmes, graduating firms lose access to 47 government support measures covering taxes, marketing and employment (OECD, 2014a).

Fourth, government support does not significantly improve SME performance. A comparison between firms three years after they began to receive public financial support through one of the four major institutions ${ }^{15}$ with firms that did not during 2003-09 found little difference in the performance of the two groups in terms of profitability and growth (KDI et al., 2011). All else equal, public support: $i$ ) failed to increase the operating profit ratio and had only a mixed impact on the net profit ratio; ii) reduced sales growth in the case of two of the support programmes; iii) improved the return on assets while lowering the

15. In addition to the SMBC, KOTEC and KCGF, this includes the Korea Fund of Funds. 
return on equity; and iv) improved the financial position by reducing the debt-to-equity ratio. Performance could be improved by focusing support on companies with high growth potential.

Figure 13. The share of government financial support ${ }^{1}$ given to SMEs according to the age of the firm

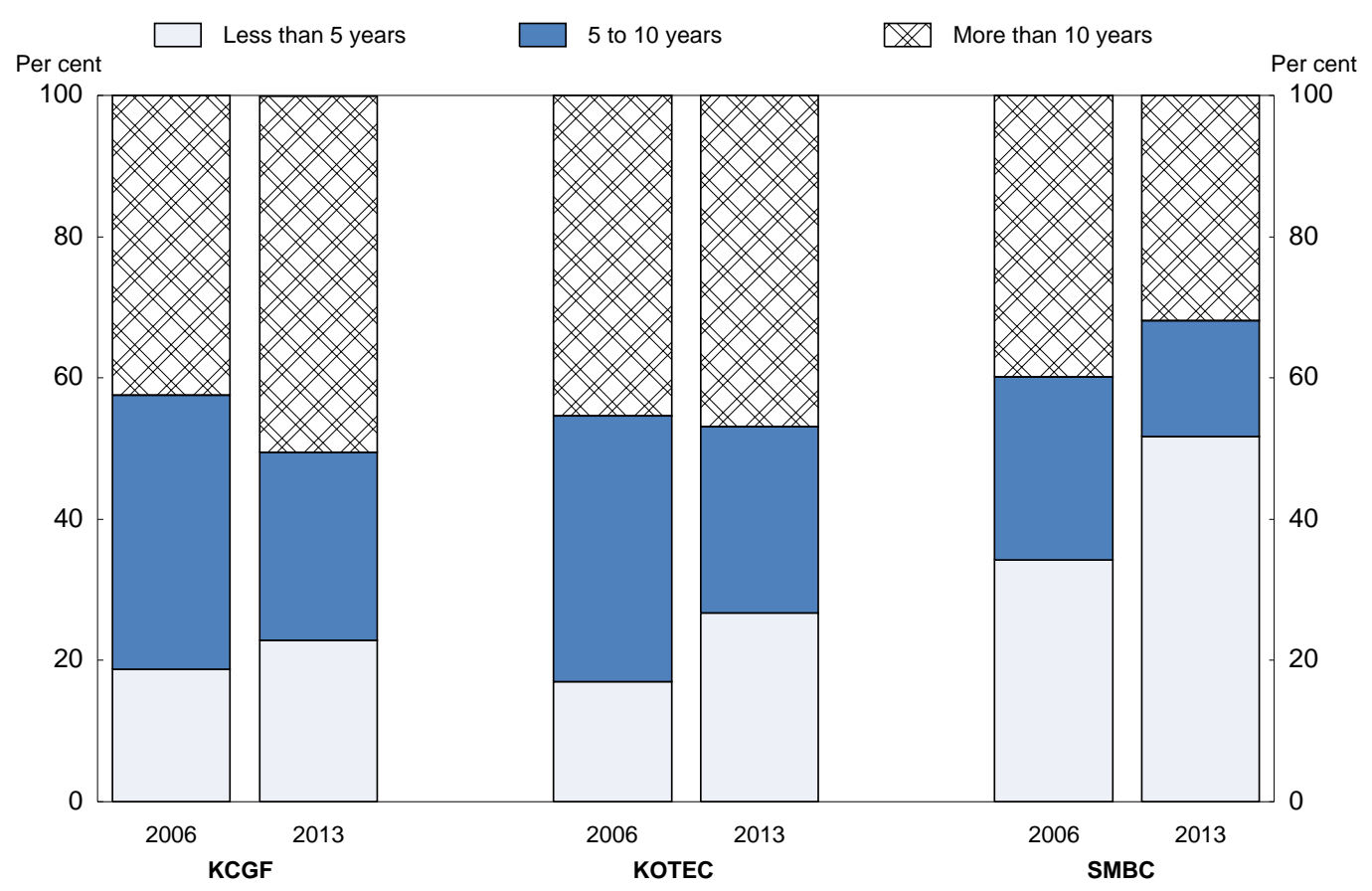

1. Loans and credit guarantees from the KCGF, KOTEC and SMBA.

Source: Hong (2012) and SMBA.

Third, a notable aspect of Korea's corporate landscape is the relatively small number of middle-sized companies. Of the several million SMEs (i.e. firms with less than 300 employees) in 2002, only 696 had expanded into mid-sized companies (defined as 300 to 999 workers) by 2012 (Statistics Korea, 2013). The low number of firms that exit the SME category, the so-called "Peter Pan syndrome", reflects the generosity and long duration of government support, as well the abrupt end to such support once companies graduate from SME status. In addition to the $1300 \mathrm{SME}$ programmes, graduating firms lose access to 47 government support measures covering taxes, marketing and employment (OECD, 2014a).

Fourth, government support does not significantly improve SME performance. A comparison between firms three years after they began to receive public financial support through one of the four major institutions ${ }^{16}$ with firms that did not during 2003-09 found little difference in the performance of the two groups in terms of profitability and growth (KDI et al., 2011). All else equal, public support: $i$ ) failed to increase the operating profit ratio and had only a mixed impact on the net profit ratio; ii) reduced sales growth in the case of two of the support programmes; iii) improved the return on assets while lowering the return on equity; and iv) improved the financial position by reducing the debt-to-equity ratio. Performance could be improved by focusing support on companies with high growth potential.

16. In addition to the SMBC, KOTEC and KCGF, this includes the Korea Fund of Funds. 


\section{The framework for public support for SMEs is inefficient}

The government is implementing a vast array of SME support measures. According to the SMBA, 14 central government ministries ran 201 programmes in 2011, with total outlays of 9.7 trillion KRW ( $0.8 \%$ of GDP) (Table 4). In addition, the 16 provincial governments and 130 SME-related organisations administered another 1101 programmes. The number of programmes is excessive, resulting in significant duplication and a waste of resources. For example, more than half of the SMEs that received financial support from the SMBC in 2012 also benefited from financial aid from other public agencies (Yoon, 2012) ${ }^{17}$ The proliferation of programmes has created a complex and confusing landscape for start-ups and SMEs (OECD, 2014a). The large number of SME programmes reflects weak linkages between the 14 central government ministries and the absence of a central authority to co-ordinate programmes. As a result, the size of SME support is determined incrementally by individual ministries, without adequate oversight, resulting in duplication and overlap. Another source of waste in public support is the large and rising share of credit guarantees from public institutions for SMEs with good credit ratings, which could likely obtain financing without public assistance. The share of KCGF guarantees to SMEs with a rating of B3 and above ${ }^{18}$ increased from $15 \%$ in 2005 to $37 \%$ in 2011 (Yang et al., 2013).

Table 4. Central government programmes to support SMEs

In billion KRW in 2011

\begin{tabular}{l|r|c|c}
\hline & Outlays & Per cent of total & Number of programmes \\
\hline SME financing & 5387 & 55.3 & 39 \\
Establishing new firms and ventures & 244 & 2.5 & 10 \\
Marketing and exports & 154 & 1.6 & 27 \\
Human resources & 576 & 5.9 & 21 \\
Innovation & 1662 & 17.1 & 43 \\
Co-operation with large companies & 291 & 3.0 & 8 \\
Other & 1433 & 14.7 & 53 \\
\hline Total & 9746 & 100.0 & 201 \\
\hline
\end{tabular}

Source: KDI et al. (2011).

\section{Directions for reform to improve government programmes for SMEs}

The government has long recognised that credit guarantees in Korea are higher than in most other countries (MOFE et al., 2005). However, SME support was increased to mitigate the impact of the 2008 crisis, and was boosted further in 2010. One key to reversing the upward trend is to sharply cut the number of SME programmes to reduce duplication and overlap. The SMBA is launching the "Comprehensive Management System for SME Support" to help determine which firms receive multiple benefits from the government, thus indicating overlap. In addition, the government plans to strengthen the performance evaluation of programmes. Finally, there should be prior consultations among ministries whenever a new programme is proposed. More generally, SME support should be limited by focusing on market failures and boosting efficiency, leaving concerns about social cohesion to the social welfare system.

17. One company received 380 million KRW (\$366 thousand) in 2010, around one-half of its annual sales, from four programmes run by three different ministries (KDI et al., 2011).

18. The KCGF credit rating system divides SMEs into six groups, S, A, B, C, D and E, with C defined as "normal" and B is defined as "good". Within the B category, there are four grades from B4 to B1. 
SME programmes should also be improved to reduce the negative effects discussed above. First, support to mature SMEs should be decreased to allow more focus on young firms and new start-ups, where the difficulty of securing market financing is greatest. As successful SMEs mature, their default rate declines and they develop links to financial institutions, enabling them to obtain market-based financing. To increase the focus on young firms, Korea should also introduce a graduation system to prevent SMEs from receiving long-term support. Of the $1300 \mathrm{SME}$ programmes, only 50 have a time limit (KDI et al., 2011). In addition, the price of guarantees paid by SMEs should increase over time and with the size of the guarantee to discourage long-term dependence on public assistance.

Second, the quality of government programmes should be improved by making them more market oriented by reducing the coverage ratio of credit guarantees, which are generally set at $85 \%$ and can go up to $100 \%$ in some cases, to encourage banks to be more active in monitoring credit risks. In OECD countries, loan guarantees typically cover $75 \%$ to $80 \%$ of the value of the loan (OECD, 2013c). In addition, the interest rate on government lending to SMEs should be raised closer to market levels to limit the crowding out of private financial institutions. The weak performance of firms receiving public guarantees, as noted above, suggests that firms are selected with little regard to their growth potential (KDI et al., 2011). Improving the selection process would make the SMEs a more dynamic sector that would make a greater contribution to Korea's growth.

The government should also develop the infrastructure for market-based SME financing, including the framework for credit evaluation. Small non-bank financial institutions, such as saving banks and credit unions, could be encouraged to lend to viable SMEs, given that they are local financial institutions with longstanding ties to local firms. ${ }^{19}$ The range of collateral accepted for SME lending could also be expanded beyond real estate. Although SMEs, especially start-ups, tend to have few tangible assets, many have intellectual property. A 2012 law created the legal basis for lending based on intangible assets, but no loans have been made thus far on the basis of intellectual property (FSS, 2013b). Finally, the authorities should pay close attention to risks in the SME sector, even though the delinquency rate of SME loans has stayed low (FSS, 2013a). Encouraging financial institutions to maintain a large buffer against potential losses from SME loans would enable them to focus on closing non-viable SMEs and restructuring troubled firms.

\section{Make greater use of the Internet to make SMEs more efficient}

The Internet supports entrepreneurship by decreasing the resources needed to create a business and increasing the flexibly to expand. A small firm today has access to communications and information systems that were available only to large multinationals 25 years ago. In addition to lowering barriers to entrepreneurship, the Internet can promote efficiency within firms by enabling them to lower fixed costs and outsource many activities, such as financial and human resource management, which are relatively burdensome for SMEs. Cloud computing and storage services, for example, allow entrepreneurs to buy as much data storage and computing power as needed at any given moment, without costly and time-intensive investment in infrastructure aimed at meeting peak load demands. While web-based services and infrastructure can benefit all sizes of firms, they play a particularly important role for SMEs and help level the playing field with large firms. The Internet also promotes the availability of human capital by enhancing the flexibility of working arrangements (OECD, 2014f).

The advent of the Internet implies a significant re-shuffling of the business environment in ways that intensify competition. In particular, the Internet has extended the geographic reach of firms, especially those that are young and small, opened new ways of delivering products and expanded consumer choice. The Internet thus facilitates the entry of new firms by lowering transaction costs, which are particularly

19. Saving banks were originally consumer finance companies. The government legalised them as regional financial institutions, which prohibits them in principle from having bank branches across provinces. 
burdensome for small firms, in part by cutting out middle men. Many intermediaries historically based their business models on the fact that it was difficult for suppliers and final customers to contact each other directly. The Internet can thus help firms integrate their supply chains. The Internet also enhances price transparency, thereby strengthening competition, which can help start-ups compete with established firms.

The extent to which an economy can benefit from the opportunities afforded by the Internet depends on several factors. First, regulations may prevent entrepreneurs from experimenting and taking risks needed to succeed, making it essential to revise the regulatory framework in line with technological development. Second, a lack of Internet competence may be an obstacle. ICT skills are necessary for both entrepreneurs, as the Internet becomes more engrained in work processes, and for the general population to benefit from new services offered on the Internet. Korea has great potential, as a front-runner in ICT. Indeed, the share of the population with wireless broadband connections is the highest in the OECD. Nevertheless, the share of firms selling on-line is one of the lowest in the OECD (Figure 14). It is important to identify the obstacles that hinder business use of the Internet.

Figure 14. Share of companies that sell their goods and services on the Internet

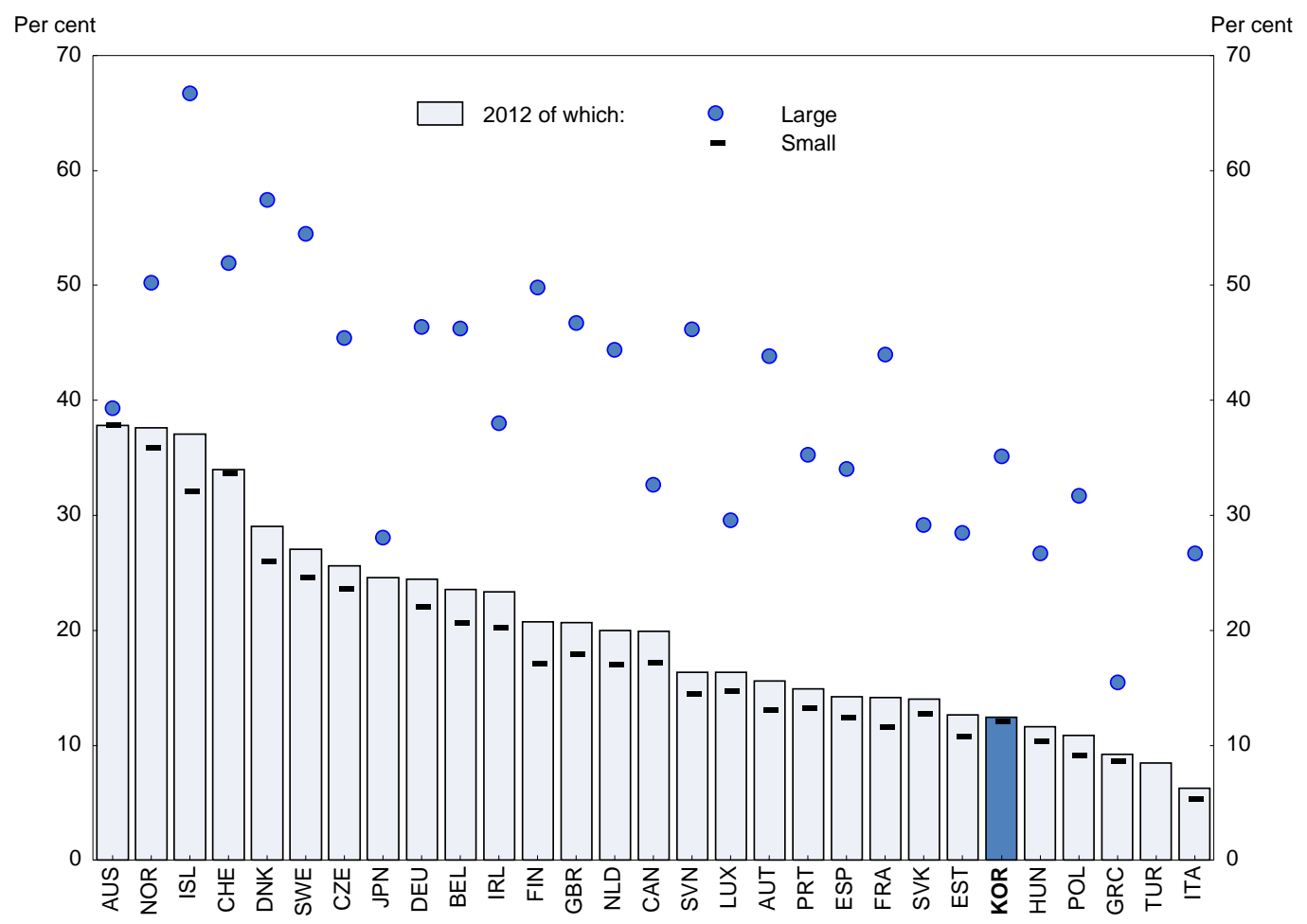

Source: OECD (2014f).

\section{Reducing labour mismatches: ensuring appropriate human capital for SMEs}

As noted above, the share of tertiary graduates among young adults (25 to 34 ) in Korea is the highest in the OECD. However, graduates tend to avoid jobs in SMEs. In 2011, 43\% of small firms faced a labour shortage and another $40 \%$ expected to face one, according to a government survey. Firms blamed shortages on a lack of qualified job applicants, their high expectations and the low wages and benefits offered by SMEs, reflecting their low productivity. One alternative is foreign workers, who receive five-year nonrenewable visas to work in Korea. For 2013, the number of ethnic Koreans from foreign countries allowed to work in Korea was held to 303 thousand, while the number of foreign workers allowed to enter the country was set at 62 thousand ( $0.2 \%$ of the labour force), as against 39 thousand leaving Korea (MOEL, 
2012). Most foreign workers (52 thousand) were allocated to manufacturing. There is severe competition from SMEs for foreign workers.

In order to fundamentally address the SME labour shortage, it is necessary to reduce the mismatch in the labour market. In 2011, 24\% of youth with tertiary education were "neither in employment nor in education or training" (NEETs) (Figure 15).

It is thus essential to reduce the overemphasis on tertiary education by improving vocational education at both the secondary and tertiary levels and expanding training that meets the needs of SMEs (2012 OECD Economic Survey of Korea). Reducing the blind pursuit of higher education is difficult as it is driven by the national consensus that it is the key to success (Jones, 2013). A university degree has become the standard expectation, regardless of capabilities or career aspirations. It is necessary to gradually shift the focus from chasing the status and prestige of high-ranking universities to rewarding the acquisition of skills that are demanded in the labour market. The government has made an important start in this direction in 2008 by introducing Meister schools, which emphasise workplace training, based on the German model of training master craftsmen. Thus far, 35 Meister schools have been created (OECD, 2014e).

Figure 15. Korea has a high share of youth who are neither in employment nor in education or training

Per cent of youth $15-29$ years old in $2011^{1}$

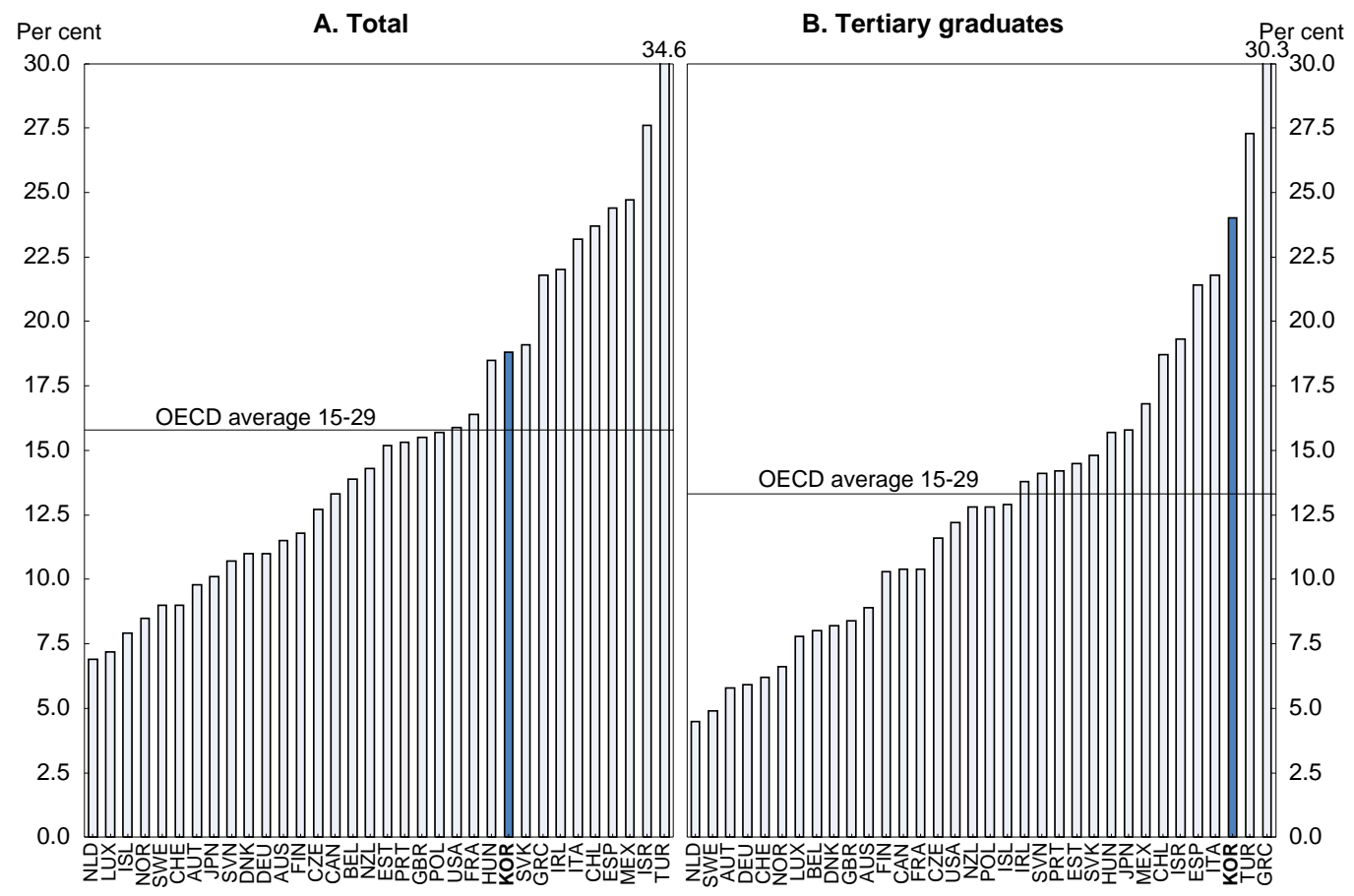

1. Data on the category ISCED4 are not available for Korea. The NEET population thus includes some people who are in training for employment or for tertiary education exams.

Source: OECD (2013e).

\section{Competition from chaebol-affiliated firms}

Chaebols are often blamed for the problems of SMEs (NCCP, 2013). In response to the 1997 crisis, the government introduced comprehensive reforms of corporate governance and accounting and disclosure practices, and required chaebols to reduce their debt-to-equity ratio from $500 \%$ at end-1997 to $200 \%$ (OECD, 2000). In addition, 17 of the top 30 chaebols went through some type of rehabilitation procedures 
(Lim, 2012), ending the "too big to fail policy". The easing of the ceiling on foreign ownership increased the share of foreign investors from 13\% of listed companies in 1996 to 33\% in 2013. Combined with a liberalisation of regulations on M\&As, chaebol owners face increased checks on their power.

However, after a period of consolidation, the number of chaebol-affiliated companies is rising again. By 2010, companies affiliated with the ten-largest chaebols accounted for half of the value on the stock exchange and Samsung alone accounted for a fifth of Korean exports, prompting the Korea Fair Trade Commission (KFTC), the competition authority, to implement new measures. First, new circular shareholding between chaebol affiliates was banned (cross-shareholding has been banned since 1987). Second, regulations on intra-chaebol trading were tightened to prevent major shareholders from using such transactions to subsidise affiliated firms or related persons. Concern that some large companies take advantage of small firms, for example, by arbitrarily demanding price cuts, led to a strengthening of the subcontracting law. In particular, the range of unfair practices subject to punitive damages has been enlarged. In principle, market forces should promote "win-win" co-operation between SMEs and chaebols, as large firms' success in global competition depends in part on mutually-beneficial relationships with suppliers. Around half of SMEs supply chaebol-affiliated firms.

Although the chaebols have succeeded in a number of heavy industries, such as cars and shipbuilding, they have looked for new growth opportunities, fuelling criticism that they are encroaching on markets traditionally dominated by SMEs. In response, the National Commission for Corporate Partnership, a private committee, launched negotiations in 2011 among enterprises on business areas to be restricted to SMEs. It was agreed to reserve 100 business lines, including restaurants, bakeries and car repair, for SMEs for three to six years. However, preventing the entry of large firms from important markets, many in services, and restricting their expansion in industries where they are already operating reduces aggregate productivity and consumer welfare. Rather than reducing their opportunities in Korea, the government should make the domestic market attractive for all firms, including chaebols, whose share of domestic employment fell from 18\% in 1995 to $12 \%$ in 2010 as they internationalised their operations. Policy should focus on enforcing competition policy and improving corporate governance of chaebols. Although the framework has been substantially improved since 1997, notably by introducing independent directors, limiting the control of the founding families remains a challenge. The goal should be to ensure that noncontrolling shareholders are not expropriated by the families, which maintain control through circular shareholding. The corporate governance framework could be improved, in particular by ensuring the independence of audit committees. Finally, given that some SMEs will not be able to compete with chaebol-affiliated firms, it is essential to further develop the social safety net. In addition, it is essential to raise the retirement age from firms to reduce the number of low-productivity SMEs (2014 OECD Economic Survey of Korea).

\section{Box 2. Summary of recommendations to foster a creative economy}

\section{Upgrade the innovation system}

- Improve universities and expand their co-operation with the business sector in R\&D, while increasing the contribution of government research institutes.

- Expand Korea's international linkages in science and innovation from their current low level.

Improve framework conditions to accelerate the implementation of innovation

- Liberalise product market regulations and reduce obstacles to international competition to promote an efficient allocation of resources in favour of innovative firms.

- $\quad$ Enhance labour market flexibility to expand the ability of innovative firms to grow and implement their ideas. 


\section{Promote the venture business sector and new start-ups}

- $\quad$ Make the new KONEX a key player in funding start-ups, while ensuring adequate investor protection in KONEX and for crowd-funding.

- $\quad$ Activate the market for M\&As by addressing the obstacles that have kept it small.

- Avoid excessive public funding of venture capital investment that would crowd out private investment, rely on a "fund-of-funds" approach and focus public support on the early stage of a firm's development when attracting private investors is most difficult.

- Develop the demand side of the venture capital market, in part by using public institutions to enhance the quality of investment projects.

- $\quad$ Foster an environment that allows failed entrepreneurs to have second chances to launch start-ups.

\section{Make SMEs part of the creative economy}

Improve policies to finance SMEs

- $\quad$ Target public loans and credit guarantees on young firms and startups, which struggle most to obtain market financing, introduce a graduation system to prevent firms from receiving long-term support and reduce public credit guarantees to firms with a credit rating high enough to obtain market financing by themselves.

- $\quad$ Strengthen the market orientation of SME programmes by: i) raising interest rates on public SME loans closer to market levels; ii) lowering the coverage ratio of the guarantees; and iii) more clearly differentiating the price of guarantees based on their length and size.

- Improve the selection of SMEs that receive public support by focusing on firms with the potential to upgrade their performance by analysing their competitiveness and technological capacity.

Strengthen the infrastructure for market-based SME financing

- Use the government's expertise to enhance the infrastructure for credit evaluation of SMEs by private financial institutions.

- Encourage a larger role for local non-bank financial institutions, such as saving banks and credit unions, in lending to viable SMEs.

- Develop the infrastructure for using non-tangible collateral, including intellectual property, for private-sector loans.

Reduce the number of government programmes for SMEs

- Reduce the generosity of SME support to weaken the disincentives for small firms to grow out of the SME category, thereby increasing their productivity through economies of scale.

- $\quad$ Gradually reduce the number of SME programmes through stronger ex post evaluation of SME programmes to focus the budget on those that are most effective and expand prior consultations among ministries before introducing new programmes.

- Use the "Comprehensive Management System" to co-ordinate SME programmes between ministries and prevent SMEs from benefiting from multiple programmes.

Enhance the competitiveness of SMEs

- Improve SMEs' human resources by reducing labour market mismatches through greater emphasis on vocational education.

- Facilitate the use of the Internet to enhance the growth of SMEs by ensuring an appropriate regulatory framework and ICT skills.

- $\quad$ Enforce fair trading rules to avoid unfair treatment of SMEs by chaebols and improve chaebols' corporate governance, while phasing out restrictions that reserve certain sectors to SMEs. 


\section{BIBLIOGRAPHY}

Andrews, D. and F. Cingano (2012), "Regulation, Allocative Efficiency and Productivity: Evidence from Firms in OECD Countries", OECD Economics Department Working Papers, No. 996, OECD Publishing, Paris, http://dx.doi.org/10.1787/5k9158wpf727-en.

Andrews, D and A. de Serres (2012), "Intangible Assets, Resource Allocation and Growth: A Framework for Analysis", OECD Economics Department Working Papers, No. 989, OECD Publishing, Paris, http://dx.doi.org/10.1787/5k92s63w14wb-en.

Andrews, D. and C. Criscuolo (2013), "Knowledge-based Capital, Innovation and Resource Allocation", OECD Economics Department Working Papers, No.1046, OECD Publishing, Paris, http://dx.doi.org/10.1787/5k46bj546kzs-en.

Andrews, D., C. Criscuolo and C. Menon (2014), "Do Resources Flow to Innovative Firms: Cross-country Evidence from Firm-level Data", OECD Economics Department Working Papers (forthcoming), OECD Publishing, Paris.

Bank of Korea (2012a), Extended 2010 Input-Output Tables, Seoul (in Korean).

Bank of Korea (2012b), Financial Stability Report 2012, Seoul (in Korean).

Board of Audit and Inspection (2012), Inspection Report: Overview of SME Financing Support, Seoul (in Korean).

Bravo-Biosca, A., C. Criscuolo and C. Menon (2012), "What Drives the Dynamics of Business Growth?", OECD Science, Technology and Industrial Policy Papers, No. 1, OECD Publishing, Paris, http://dx.doi.org/10.1787/5k486qtttq46-en.

Bouis, R., R. Duval and F. Murtin (2011), "The Policy and Institutional Drivers of Economic Growth Across OECD and Non-OECD Economies: New Evidence from Growth Regressions", OECD Economics Department Working Papers, No.843, OECD Publishing, Paris, http://dx.doi.org/10.1787/5kghwnhxwkhj-en.

Chun, H., K. Fukao, S. Hisa and T. Miyagawa. (2012), "Measurement of Intangible Investment by Industry and Its Role in Productivity Improvement Utilizing Comparative Studies between Japan and Korea," RIETI Discussion Paper Series, 12-0-037, Tokyo.

Colombo, M., L. Grilli and S. Murtinu (2011), "R\&D Subsidies and the Performance of High-Tech StartUps". Economics Letters, 112(1).

Corrado, C., J. Haskel, C. Jona-Lasinio, and M. Iommi (2012), "Intangible Capital and Growth in Advanced Economies: Measurement Methods and Comparative Results", IZA Discussion Papers, No. 6738 .

Financial Supervisory Service (2013a), Domestic Banks' Substandard and Below Loans in the Second Quarter 2013, Seoul (in Korean).

Financial Supervisory Service (2013b), Performance for Last One Year After The Introduction of Loans on the Base of Movable Collateral and Policy Measures to Promote It, Seoul (in Korean). 
Hong, C. (2012), "SME Sector", Reports for 2012-2016 National Fiscal Policy Plan: Industry, SME and Energy Sector, Korea Development Institute, August, Seoul.

Isenberg, D. (2012), “The Road to Crowdfunding Hell”, Harvard Business Review, April.

Jaumotte, F. and N. Pain (2005), "From Ideas to Development: The Determinants of R\&D and Patenting", OECD Economics Department Working Papers No.457, OECD Publishing, Paris, http://dx.doi.org/10.1787/702226422387.

Jones, R. (2013), "Education Reform in Korea", OECD Economics Department Working Papers, No. 1067, OECD Publishing, Paris, http://dx.doi.org/10.1787/5k43nxs1t9vh-en.

Jones, R. and M. Kim (2014), "Policies to Promote the Financing of SMEs and Start-ups in Korea", OECD Economics Department Working Papers (forthcoming), OECD Publishing, Paris.

Kim, D., M. Kim, Y. Kim and S. Kim (2012), "An Analysis of the Sources of Korean Growth, 19702010”, Korea Development Institute Research Report, No. 2012-08, Seoul (in Korean).

Kim, J. and J. Koo (2010), "Enhancing the Efficiency of Financial Intermediary Functions of Financial Institutions", The Direction for Development of Korean Economy after the Global Financial Crisis, Korean Development Institute, Seoul.

Kleer, R. (2010), "Government R\&D Subsidies as a Signal for Private Investors", Research Policy, Vol. 39, Issue 10.

Koh, Y., S. Kim, C. Kim, Y. Lee, J. Kim, S. Lee and Y. Kim (2010), "Social Policy", in The Korean Economy: Six Decades of Growth and Development, edited by I. SaKong and Y. Koh, Korea Development Institute, Seoul.

Korea Development Institute, Korea Small Business Institute and Research Institute for the Assessment of Economic and Social Policies (2011), In-Depth Study on Fiscal Programmes 2010: the SME Sector, Seoul (in Korean).

Korea Venture Capital Association (2013), Venture Capital Newsletter, Vol. 83, October (in Korean).

Koske, I., I. Wanner, R. Bitetti and O. Barbiero (2014), "The 2013 Update of the OECD Product Market Regulation Indicators: Policy Insights for OECD and non-OECD Countries", OECD Economics Department Working Papers (forthcoming), OECD Publications, Paris,

Lerner, J. (2012), Boulevard of Broken Dreams: Why Public Efforts to Boost Entrepreneurship and Venture Capital Have Failed - and What to Do About It, Princeton: Princeton University Press.

Lim, K. (2010), "Structural Fundamentals of Korean Corporations: This Time Was Different", in M. Obstfeld, D. Cho and A. Mason (eds), Global Economic Crisis: Impact, Transmission and Recovery, Edward Elgar Publishing.

Martin, J. and S. Scarpetta (2012), "Employment Protection, Labour Reallocation and Productivity", De Economist, p. 160.

Ministry of Employment and Labour (2012), "Foreign Workers to be Introduced Earlier to Ease Labor Shortages Among SMEs", News, 17 September. 
Ministry of Finance and Economy (MOFE), Financial Supervisory Commission and Small and Medium Business Administration (2005), Restructuring the Institutional Framework for SME Financing Support, Seoul (in Korean).

Ministry of Strategy and Finance (2013), “The Park Geun-hye Administration's Creative Economy Blueprint, 'Creative Economy Action Plan and Measures to Establish a Creative Economic Ecosystem"”, Press Release, 5 June.

Ministry of Strategy and Finance, Ministry of Science, IT and Future Planning, Ministry of Justice, Ministry of Trade, Industry and Energy, Financial Supervisory Committee, Fair Trade Commission and Small and Medium Business Administration (2013), Policy Measures to Create a Virtuous Cycle in the Venture Start-up Capital Ecosystem, Seoul (in Korean).

National Commission for Corporate Partnership (NCCP) (2013), Grow Together, Seoul.

Noh, H. and H. Lee (2013), "Current Situation of Marginal Companies and Implications", CEO Report No. 13-8, Woori Finance Research Institute, Seoul (in Korean).

OECD (2000), OECD Economic Survey of Korea, OECD Publishing, Paris, http://dx.doi.org/10.1787/eco_surveys-kor-2000-en.

OECD (2006), "The SME Financing Gap: Theory and Evidence”, Financial Market Trends, Vol. 2006/2, OECD Publishing, Paris, http://dx.doi.org/10.1787/fmt-v2006-2-en.

OECD (2007), Jobs for Youth: Korea, OECD Publishing, Paris, http://dx.doi.org/10.1787/9789264040809en.

OECD (2009), OECD Reviews of Tertiary Education: Korea, OECD Publishing, Paris, http://dx.doi.org/10.1787/9789264049055-en.

OECD (2012a), OECD Economic Survey of Korea, OECD Publishing, Paris, http://dx.doi.org/10.1787/eco_surveys-kor-2012-en.

OECD (2012b), OECD Science, Technology and Industry Outlook 2012, OECD Publishing, Paris, http://dx.doi.org/10.1787/sti_outlook-2012-en.

OECD (2013a), Economic Policy Reforms 2013: Going for Growth, OECD Publishing, Paris, http://dx.doi.org/10.1787/growth-2013-en.

OECD (2013b), Entrepreneurship at a Glance, OECD Publishing, Paris, http://dx.doi.org/10.1787/entrepreneur_aag-2013-en.

OECD (2013c), Financing SMEs and Entrepreneurs 2013: An OECD Scoreboard, OECD Publishing, Paris, http://dx.doi.org/10.1787/fin_sme_ent-2013-en.

OECD (2013d), "Knowledge-Based Capital Innovation and Resource Allocation", OECD Economic Policy Papers, No. 04, OECD Publishing, Paris, http://dx.doi.org/10.1787/5k46bh92lr35-en.

OECD (2013e), OECD Education at a Glance, OECD Publishing, Paris, http://dx.doi.org/10.1787/eag2013-en. 
OECD (2013f), OECD Science, Technology and Industry Scoreboard 2013, OECD Publishing, Paris, http://dx.doi.org/10.1787/sti_scoreboard-2013-en.

OECD (2013g), PISA 2012 Results: What Students Know and Can Do (Volume I), OECD Publishing, Paris, http://dx.doi.org/10.1787/9789264208780-en.

OECD (2013h), Supporting Investment in Knowledge Capital, Growth and Innovation, OECD Publishing, Paris, http://dx.doi.org/10.1787/9789264193307-en.

OECD (2014a), Country Review of Korean Policies for Industry and Technology, (forthcoming), OECD Publishing, Paris.

OECD (2014b), Economic Policy Reforms 2014: Going for Growth Interim Report, OECD Publishing, Paris, http://dx.doi.org/10.1787/growth-2014-en.

OECD (2014c), Main Science and Technology Indicators, Volume 2013 Issue 2, OECD Publishing, Paris, http://dx.doi.org/10.1787/msti-v2013-2-en.

OECD (2014d), OECD Economic Survey of Korea, OECD Publishing, Paris

OECD (2014e), OECD Skills Strategy Diagnostic Report: Korea (forthcoming), OECD Publishing, Paris.

OECD (2014f), “The Internet Supporting SMEs and Entrepreneurship”, (forthcoming), OECD Publishing, Paris.

Small and Medium Business Administration (2013), Policy Measures to Promote Productivity of SMEs for Accomplishing a Creative Economy, Daejeon (in Korean).

Sohn, S. and D. Kim (2013), Tasks for the Development of SME Financing, Korea Institute of Finance, Seoul.

Statistics Korea (2013), National Survey of Enterprises, Daejeon (in Korean).

Westmore, B. (2013), "R\&D, Patenting and Growth: The Role of Public Policy", OECD Economics Department Working Papers, No.1047, OECD Publishing, Paris, http://dx.doi.org/10.1787/5k46h2rfb4f3-en.

Yang, J., H. Noh and H. Lee (2013), Proposals for Enhancing Financial Support for SMEs, Woori Finance Research Institute, February 2013, Seoul (in Korean).

Yoon, S. (2012), Evaluation of SME Financing Support Programmes, National Assembly Budget Office, Seoul. 
ECO/WKP(2014)48

\section{WORKING PAPERS}

The full series of Economics Department Working Papers can be consulted at www.oecd.org/eco/workingpapers

1151. Economic uncertainties and their impact on activity in Greece compared with Ireland and Portugal

(July 2014) by Jan-David Schneider and Claude Giorno

1150. Workplace stress in the United States: issues and policies

(July 2014) by Michael Darden

1149. Taxing the rent of non-renewable resource sectors: a theoretical note (July 2014) by Julien Daubanes and Saraly Andrade de Sá

1148. Health, work and working conditions: a review of the European economic literature (July 2014) by Thomas Barnay

1147 Making the best of new energy resources in the United States (July 2014) by Douglas Sutherland

1146. Improving well-being in the United States

(July 2014) by Aida Caldera Sánchez, Patrick Lenain and Sarah Fléche

1145. Deconstructing Canada's housing markets: finance, affordability and urban sprawl (July 2014) by Calista Cheung

Restructurer les marchés canadiens du logement: financements, accessibilité financière et étalement urbain (Juillet 2014) par Calista Cheung

1144. Women's role in the Swiss economy

(July 2014) by Richard Dutu

Le rôle des femmes dans l'économie suisse

(Juillet 2014) par Richard Dutu

1143. Overcoming skills shortages in Canada

(July 2014) by David Carey

Combler les pénuries de compétences au Canada

(Juillet 2014) par David Carey

1142. Trade patterns in the 2060 world economy

(July 2014) by Jean Chateau, Lionel Fontagné, Jean Fouré, Åsa Johansson and Eduardo Olaberria

1141. The Demand for Skills 1995-2008: A global chain perspective

(July 2014) by Bart Los, Marcel P. Timmer and Gaaitzen J. De Vries

1140. International migration: The relationship with economic and policy factors in the home and destination country

(July 2014) by Ben Westmore 
1139. Gross earning inequalities in OECD countries and major non-member economies: determinants and future scenarios

(July 2014) by Henrik Braconier and Jenifer Valenzuela Ruiz

1136. Long-term patterns of trade and specialisation

(July 2014) by Asa Johansson and Eduardo Olaberria

1135. Consequences of climate change damages for economic growth $-a$ dynamic quantitative assessment

(July 2014) by Rob Dellink, Elisa Lanzi, Jean Chateau, Francesco Bosello, Ramiro Parrado and Kelly de Bruin

1134. Comparing the robustness of $P A Y G$ pension schemes

(July 2014) by Falilou Fall

1133. Overcoming vulnerabilities of pension systems

(July 2014) by Falilou Fall and Debbie Bloch

1132. Overcoming vulnerabilities of health care systems

(July 2014) by Mauro Pisu

1131. Overcoming vulnerability of unemployment insurance schemes

(July 2014) by Jon Pareliussen

1130. Vulnerability of social institutions: Lessons from the recent crisis and historical episodes

(July 2014) by Falilou Fall, Mauro Pisu, Jon Pareliussen and Debbie Bloch

1129. An update of the OECD international trade equations

(June 2014) by Myriam Morin and Cyrille Schwellnus

1128. What explains the volume and composition of trade? Industrial evidence from a panel of countries

(June 2014) by Asa Johansson, Przemyslaw Kowalski, Eduardo Olaberria and Dario Pellegrino

1127. Do resources flow to patenting firms: cross-country evidence from firm level data

(June 2014) by Dan Andrews, Chiara Criscuolo and Carlo Menon

1126. Macroprudential policy tools in Norway: Strengthening financial system resilience

(June 2014) by Yosuke Jin, Patrick Lenain and Paul O’Brien

1125. Strengthening competition in Poland

(June 2014) by Balász Égert and Antoine Goujard

1124. Making the labour market work better in Poland

(June 2014) by Hervé Boulhol

1123. Enhancing competition and the business environment in Hungary

(June 2014) by Alvaro Pina

1122. Tackling labour mismatches and promoting mobility in Hungary

(June 2014) by Stéphane Sorbe 